\title{
Limited Şirket Esas Sermaye Payının İnançlı Temliki: Basel Eyalet Mahkemesinin 3 Şubat 2019 Tarihli Zb.2018.35 Sayılı Kararı Çerçevesinde Bir İnceleme
}

\author{
Fiduciary Assignment of Limited Company Shares: A Research \\ Regarding The Basel Supreme Court Decision Dated 3 February 2019 \\ Numbered Zb.2018.35
}

Murat Yusuf Akın $^{* *}$ (D), Emine Develi Ayverdi ${ }^{* *}$ (D)

\section{öz}

6102 sayılı Türk Ticaret Kanunu’nun* (“TTK”) 600. maddesi ile limited şirket esas sermaye payının rehni ilk defa açıkça düzenlenmiştir. Ancak rehin hakkının rehin alacaklısına sağladığı hakların kısıtlılığı uygulamada esas sermaye payının inançlı temlike konu edilmesi sonucunu doğurmuştur. $\mathrm{Bu}$ noktada inançlı temlikin, kanun koyucu tarafından düzenlenmemiş olup doktrin ve uygulama tarafından geliştirilmiş olması, esas sermaye payının inançlı işlemle devredilmesi sonucu tarafların hukuki konumu hakkında belirsizliğe yol açmaktadır.

Alacağını teminat altına almak isteyen alacaklı için hem avantajları hem de dezavantajları bulunan bu kurum, beraberinde bilhassa tarafların yetkisine ilişkin birtakım sorunları getirmektedir. Bu çalışmada söz konusu olabilecek sorunlara değinilerek doktrinin görüşleri çerçevesinde çözüm getirilmeye çalışılmıştır.

Anahtar Kelimeler: Limited Şirket Esas Sermaye Payı, İnançlı Temlik, Meşru Hak Sahipliği Görüntüsü Yaratma Amaciyla Devir

\section{ABSTRACT}

Turkish Commercial Code numbered 6102 (TTK) article 600 explicitly regulates the pledge on limited company shares for the first time. However, the limitation of the rights granted to the pledgee brings forth the fiduciary assignment of limited company shares in practice. At this point, since fiduciary assignment is a term promoted by the doctrin and not regulated in law, legal status of the assignee and assigner after the fiduciary assignment of limited company share is blurry.

This institution that brings about both perks and handicaps for assignee causes problems most particularly regarding the authority of parties. In this study it is intended to offer solutions to possible problem with regards to doctrin.

Keywords: Limited Company Share, Fiduciary Assignment, Legitimitation Transfer

* $\quad$ RG, 14.2.2011, S. 27846 .

** Doç. Dr., Marmara Üniversitesi Hukuk Fakültesi Ticaret Hukuku Anabilim Dalı

*** Ar. Gör., Sakarya Üniversitesi Hukuk Fakültesi Ticaret Hukuku Anabilim Dalı, edeveli@sakarya.edu.tr, ORCID: 0000-0001-6373-3218. Sorumlu Yazar/Correspondence Author: Murat Yusuf Akın

E-posta/E-mail: makin@marmara.edu.tr

Geliş Tarihi/Received: $\quad 14.12 .2020$

Kabul Tarihi/Accepted:

24.01.2021 


\section{Giriş}

Limited şirket esas sermaye payı 4721 sayılı Türk Medeni Kanunu ${ }^{1}$ madde 954 hükmü çerçevesinde “diğer haklar” dan sayılmakta olup, rehni kabil bir hak teşkil eder. Dolayısıyla alacaklı, alacağına teminat olarak borçlunun veya üçüncü kişinin esas sermaye payı üzerinde kendi lehine rehin hakkı tesis etmesini talep edebilir. Bu sayede rehin alacaklısı, rehin hakkı ile teminat altına alınan alacağın ifa edilmemesi halinde rehne konu esas sermaye payını sattırarak alacağına kavuşabilir. Lakin esas sermaye payı üzerinde tesis edilen rehin hakkının sağlamış olduğu teminat, ileride değinileceği üzere, her zaman rehin alacaklısını tatmin konusunda yeterli olmayabilir. Özellikle rehin hakkının ortaksal hakları bahşetmemesi ve değerinde azalma yaşanmasını önleme imkânının rehin alacaklısına tanınmamış olması rehin hakkının teminat sağlama işlevinde yetersiz kalmasına sebep olabilir. Bunun gibi sebeplerden ötürü taraflar esas sermaye payının inançlı temlik yoluyla devredilmesine karar verebilir. Tarafların buna karar vermesi halinde inançlı temlikin hangi usulde yapılacağı, taraflar arasındaki iç ilişki ve dış ilişki, inançlı işlemle devreden borçlunun korunması gibi hususlar büyük önem arz eder. Bunun yanı sıra bu çalışmada özetine yer verilen Basel Eyalet Mahkemesi kararına konu uyuşmazlıkta olduğu üzere, inançlı işlem ile devrin esas sermaye payı üzerindeki mülkiyet hakkına etkisi, özellikle devredenin bu esas sermaye payından doğan hakları haiz olup olmadığı noktasında, oldukça önemli olup bu konuya yaklaşımlar Türk-İsviçre hukukları ile Alman hukukunda farklılık göstermektedir.

Çalışma, limited şirket esas sermaye payının inançlı temlik ile devrini konu almakta olup, diğer hak türleri, özellikle anonim şirket payları kapsam dışında bırakılmıştır. Esas sermaye payının inançlı temlike konu olması hususunda özellikle bu devrin esas sermaye payı üzerindeki mülkiyet hakkına etkisi noktasında Türk-İsviçre hukukları ile Alman hukukundaki farklı yaklaşım incelenmek istenmiştir. Çalışmanın kapsamı bakımından Basel Eyalet Mahkemesi kararına konu olaydaki nam-ı müstearın bir inançlı işlem türü olup olmadığı tartışmasına da yalnızca işaret edilmiştir.

\section{ESAS SERMAYE PAYININ INANÇLI TEMLIKE KONU OLMASINA ILIŞKIN AÇIKLAMALAR}

\section{A. GENEL OLARAK}

İnançlı işlemler (fiduziarische / treuhänderische Rechtsgeschäfte), kanunda hiç yer verilmemiş olmasına rağmen ${ }^{2}$ uygulamada sıklıkla karşımıza çıkmaktadır. İnançlı işlemlerin bir türü olan ve gizleme, alacaklılardan mal kaçırma, dolambaç, sadeleştirme ve teminat sağlama gibi iktisadi fonksiyonlarından bahsedilen inançlı temlik, her ne kadar kanun koyucu bu kurumu göz ardı etmiş olsa da doktrin ve yargı kararları tarafından geçerli kabul edilmektedir. İnançlı temlike ilişkin olarak

RG, 8.12.2001, S. 24607.

2 Bir taşınırın mülkiyetini hükmen teslim yoluyla devrini düzenleyen TMK 766 ve emre ve hamiline yazılı senetlerin inançlı temlik ile devredildiği halde iflas masasından çıkarılması hakkını düzenleyen İ̇K 188, dolaylı da olsa inançlı temliki konu alan hükümlere örnek gösterilebilir, bkz. Altaş, H./ Kurt, L., İnançlı İşlemler, İnönü Üniversitesi Hukuk Fakültesi Dergisi 2011, C. II, S.II, (s. 1-28) s. 2 dn.1. 
doktrinde farklı tanımlara yer verilmekte olup, bunların birleştiği tüm noktaları kapsayan tanım şu şekildedir: "İnanamin bir borca teminat teşkil etmek veya idare olunmak üzere malvarlğına dahil bir şey ya da hakkı, aynı amacı güden olağan hukuki işlemlerden daha güçlü bir hukuki durum yaratmak maksadiyla inanilana ciddi biçimde ve tam olarak kazandıran, sonra da tekrar (geri) devretme yükümlülüğünü içeren işlemdir”3.

Tanımda yer verilen unsurların incelenmesinden önce inanç ilişkisinde taraflara ve sözleşmeye ilişkin adlandırmalardan bahsedilmesi yerinde olur. İnançlı temlikte malvarlığındaki malı veya hakkı inançlı devreden kişi "inanan" (Fiduziant / Treugeber), malı veya hakkı inançlı devralan kişi ise "inanılan" (Fiduziar / Treuhänder), aralarındaki malın veya hakkın inançlı olarak devredilmesine ilişkin anlaşma "inanç anlaşması" (pactum fiduciae / fiduziarische Vereinbarung / Treuabrede) olarak adlandırılır. İnançlı temlik işleminin teminat sağlama amacıyla yapılması halinde ise, inanan, aynı zamanda "teminat veren" (Sicherungsgeber); inanılan da, "teminat alan" (Sicherungsnehmer) olarak nitelendirilir.

İnançlı temlike ilişkin olarak yukarıda verdiğimiz tanım ayrıntılı olarak incelendiğinde inançlı temlikin unsurları ortaya çıkmaktadır. İnançlı temlikten söz edebilmek için öncelikle tarafların esas olarak amaçladıkları hukuki işlemden daha öteye giden bir işlem yapmış olmaları gerekmektedir. Buna örnek olarak, çalışmamızın bu kısmında ele alacağımız üzere, teminat sağlamak amacıyla rehin hakkı tesis etmek yerine mülkiyetin devredilmesi verilebilir. Bir diğer önemli unsur ise, inançlı işlem konusunun ciddi biçimde ve tam olarak inanılana devrinin istenmesidir. Bu unsur inançlı temliki muvazaadan ayırır ${ }^{4}$. Muvazaanın aksine taraflar üçüncü kişilere karşı hakkın devredilmişgörünmesini değil, kendi aralarında da sonuç doğurmak üzere hakkın tam olarak devrini istemektedirler. "Tam hak devri” olarak ifade edilen bu teori Türk-İsviçre hukukunda kabul edilmektedir ${ }^{5}$. O kadar ki, devir

3 Esener, T., Türk Hususi Hukukunda Muvazaalı Muameleler, Fakülteler Matbaası, İstanbul 1956, s.152-155; Esener, Borçlar Hukuku I, s. 107; Tandoğan, H., Borçlar Hukuku - Özel Borç İlişkileri - Cilt: II, 5. Baskı, Vedat Kitapçılık, İstanbul 2010, s. 543; Aydıncık, Ş., "Bir İnançlı İşlem Olarak Alacağın Teminat Amacıyla Temliki”, IUÜHFM, C. LXIV, S. 1, 2006, (s. 131-194) s. 131; Eren, F., Borçlar Hukuku Genel Hükümler, 23. Bası, Yetkin Yayınları, Ankara 2018, s. 383; Antalya, G., Borçlar Hukuku Genel Hükümler C. V/ 1,1, 2. Bası, Seçkin Yayıncılık, Ankara 2019, § 15 N $1526 ;$ Kılıçoğlu, A., Borçlar Hukuku Genel Hükümler, Genişletilmiş 23. Bası, Turhan Kitabevi, Ankara 2019, s. 245; Kocayusufpaşaoğlu, N./ Hatemi, H./ Serozan, R./Arpacı, A., Borçlar Hukuku Genel Bölüm, C. I, 6. Bası, Filiz Yayınevi, İstanbul 2014, \$ 35, Nr. 37; Tandoğan, H., "İnançlı İşlemlerde İnananın Korunması Sorunu ve Bu Sorunun Çözümünde BK.393’ten Yararlanma Olanağı", Temsil ve Vekalete İlişkin Sorunlar, Sempozyum, İstanbul 1977, s. 73; Şafak, A., Teminat Amaçlı Alacağın Temliki, 2. Basım, Seçkin Yayıncılık, Ankara 2017, 24; Yasaman, H., Hisse Devir İşlemi, Şirketler Hukuku Ve Sermaye Piyasası Hukuku İle İlgili Makaleler, Mütalaalar, Bilirkişi Raporları-II, Vedat Kitapçılık, İstanbul 2013, (s. 563-586) s. 583; Merz, H., Legalzession und Aussonderungsrecht gemäß Art. 401 OR: ein Beitrag zum Verhältnis von Auftrag und fiduziarischem Rechtsgeschäft, Erhaltung und Entfaltung des Rechts in der Rechtsprechung des Schweizerischen Bundesgerichts, Helbing und Lichtenhahn, Basel,1975, (s. 451-464) s. 451; Schmid, J. (Hrsg.) / Jäggi, P./ Gauch, P./ Hartmann, S., ZK - Zürcher Kommentar: Obligationenrecht: Art. 18 OR - Auslegung, Ergänzung und Anpassung der Verträge; Simulation, 4. Auflage, Schulthess Juristische Medien AG, Zürich 2014, Art. 18, N. 190; Guhl, T./ Koller, A./ Schnyder, A./ Druey, J. N., Das Schweizerische Obligationenrecht mit Einschluss des Handels - und Wertpapierrechts, 9. Auflage, Schulthess Juristische Medien AG, 2000, § 15, N. 26; BGE 119 II 326; BGE 71 II 99; BGE 117 II 290.

4 Yılmaz, S./ Pınar, H., "İnançlı İşlemlerin Muvazaalı İşlemlerle Karşılaştırılması Üzerinde Bir Değerlendirme”, AÜHFD, C. 68, S. 4, Y. 2019, (s. 959 - 998) s. 985.

5 Bkz. Tandoğan, H., Borçlar Hukuku - Özel Borç İlişkileri - Cilt: II, 5. Baskı, Vedat Kitapçılık, İstanbul 2010, s. 547; Eren, Borçlar Hukuku Genel Hükümler, s. 385; Esener, Borçlar Hukuku I, s. 109-110; Esener, Muvazaalı Muameleler, s. 150152; Öztürk, G., İnançlı İşlemler, Yetkin Yayınları, Ankara 1998, s. 60; Özkaya, E., İnançlı İşlem ve Muvazaa Davaları, 7. 
işleminin inançlı işlem olduğunu bilen üçüncü kişilere karşı dahi bu devir ileri sürülebilir6 ${ }^{6}$ Buna karşın muvazaada taraflar yalnızca dışarıya karşı bir görünüm oluşturmakta, ancak bu durumun iç ilişkide hüküm ifade etmesini istememektedirler. İnançlı temlikte mülkiyetin tam olarak devriyle birlikte inanılan artık devir konusunun tam sahibidir; ancak inanılan bu hakkı inananla aralarında akdettikleri sözleşmeye uygun olarak kullanma yükümlülüğ̈̈ altındadır ${ }^{7}$. Yine de ifade etmeliyiz ki, bu yükümlülük aralarındaki nispi ilişkiden kaynaklanmakta olup ${ }^{8}$, üçüncü kişilere karşı hüküm ifade etmemektedir. Örneğin, inanç konusunun bu ilişkiden haberdar üçüncü kişiye devri halinde bu devir işlemi, TBK 27 hükmüne aykırılık hali saklı kalmak üzere, geçerli olur.

İnançlı işlemler doktrinde farklı şekillerde tasnif edilmişse de bu ayrımlardan en önemlisi amaç bakımından yapılan ayrımdır. Buna göre inançlı işlemler saf inançlı işlemler (reine fiduziarische Rechtsgeschäfte / fiduciae cum amico) ve karma inançlı işlemler (gemischte fiduziarische Rechtsgeschäfte / fiduciae cum creditore contracta) olarak ikiye ayrılır ${ }^{9}$. Saf inançlı işlemlerde inanılan, inanç konusunu, sadece inanan veya onun tayin ettiği bir kişi yararına elinde bulundurur ve onun talimatlarıyla bağlıdır ${ }^{10}$. Bu ilişki vekâlet sözleşmesi veya vekâlet benzeri sözleşme olarak nitelendirilir ${ }^{11}$ ve en önemli örneğini alacağın tahsili maksadıyla temlik (Inkassoabtretung) oluşturur. Bu tür inanç işlemler aynı zamanda gerçek inançlı işlem (echtes Treuhand) olarak nitelendirilir. Alacağın tahsili amacıyla temlikine örnek olarak kambiyo senedinin tahsil amacıyla ciro edilmesi gösterilebilir ${ }^{12}$.

Karma inançlı işlemler ise inanılanın menfaatinin de göz önünde bulundurulduğu hallerde söz konusu olur. Ancak bu halde dahi malı veya hakkı elinde bulunduran inanılan, kendi menfaatini üstün tutarken inananın menfaatlerini göz ardı etmemelidir. İnançlı işlemin menfaate göre sınıflandırılmasında kendi yararına (eigennützige) inançlı işlem olarak ifade edilen karma inançlı işlemlerde, inanılanın bazı hallerde inananın menfaatine de uygun hareket etmesi beklenir ${ }^{13}$. $\mathrm{Bu}$

Bası, Seçkin Yayıncılık, Ankara 2017, s. 60 vd.; Aydıncık, s.136 vd; Jäggi / Gauch / Hartmann, Art. 18, N. 204 vd; Guhl/ Koller/Schnyder / Druey, $\$ 15$, N. 28; Meier-Hayoz, A. (Hrsg.) / Kramer, E. A. / Schmidlin, B., BK - Berner Kommentar Band / Nr. VI/1/1, Schweizerisches Zivilgesetzbuch, Das Obligationenrecht, Allgemeine Bestimmungen, Allgemeine Einleitung in das schweizerische Obligationenrecht und Kommentar zu Art. 1-18 OR, Stämpfli Verlag AG, 1986, Art. 18, Nr. 119; Merz, s. 453; Aebi-Müller, R. E. (Hrsg.) / Müller, C. (Hrsg.), BK - Berner Kommentar: Obligationenrecht, Allgemeine Bestimmungen: Art. 1-18 OR mit allgemeiner Einleitung in das Schweizerische Obligationenrecht, Stämpfli Verlag AG, 2018, Art. 18, Nr. 414-415; BGE 130 III 417; BGE 117 II 463; BGE 113 III; Basel Kantonu Temyiz Mahkemesi ZB. 2018.35 sayılı 03.02.2019 tarihli kararı.

6 Oktay-Özdemir, S., Teminat Amaçlı Alacak Devri ve Toptan Temlik Sözleşmeleri, IÜHFM, C. LVII, S. 1-2, Y. 1999, (s. 265 - 299), s. 270 dn. 12.

$7 \quad$ Kramer / Schmidlin, Art. 18, Nr. 119.

$8 \quad$ Kramer / Schmidlin, Art. 18, Nr. 123; Müller, Art. 18, Nr. 415.

9 Kocayusufpaşaoğlu / Hatemi / Serozan / Arpacı, § 35, Nr. 42; Antalya, Borçlar Hukuku Genel Hükümler C. V/ 1,1, §15 N 1536 vd.; Kramer / Schmidlin, Art. 18, Nr. 120.

10 Jäggi / Gauch / Hartmann, Art. 18, N 193.

11 Özsunay, E., Türk Hukukunda ve Mukayeseli Hukukta İnançlı Muameleler, İstanbul 1968, s. 45; Kocayusufpaşaoğlu / Hatemi / Serozan / Arpacı, \$3 5, Nr. 43; Antalya, Borçlar Hukuku Genel Hükümler C. V/ 1,1, \$15 N 1545; Jäggi / Gauch / Hartmann, Art. 18, N. 209; Merz, s. 454 vd.

12 Özsunay, İnançlı Muameleler, s. 46; Tandoğan, Özel Borç İlişkileri, s. 544.

13 Özsunay, İnançlı Muameleler, s. 67. 
tür inançlı işlemlere örnek olarak ise mülkiyetin teminat amaçlı devri (Sicherungsübertragung) veya alacağın teminat amaçlı devri (Sicherungszession) çıkmaktadır ${ }^{14}$.

Karma inançlı işlemlerin hukuki niteliğinin tespiti saf inançlı işlemlere göre daha zordur. Zira saf inançlı işlemlerde yalnızca inananın menfaati göz önünde bulundurulmakta ve inanılan onun talimatlarıyla bağlı bir konumda bulunmaktadır. Buna karşılık karma inançlı işlemlerde inanılanın menfaatleri ön plana çıkar; inanan inanç konusu üzerinde tasarrufta bulunurken inanılanın menfaatlerini de gözetmelidir ${ }^{15}$. Yine de inananın inanılana talimat vermesi söz konusu değildir ${ }^{16}$. Karma inançlı işlemler özellikle alacak veya mülkiyetin teminat amacıyla inançlı temlikinde karşımıza çıkmaktadır ${ }^{17}$. Bu nedenle karma inançlı işlemlerde uygulanacak hükümler belirlenirken, özellikle teminat amaçlı inançlı temlik halinde vekâlet sözleşmesi hükümlerinden ziyade rehin hükümlerinin kıyasen uygulanması gerektiği ifade edilmektedir ${ }^{18}$. Rehin hakkı tesis edilmesi halinde rehin alacaklısına rehin konusu üzerinde sınırlı ayni hak tanınmış olmasına karşılık teminat amacıyla inançlı temlikte inanç konusunun mülkiyeti geçirildiğine göre, rehin hükümlerinin inançlı temlike uygulanmasının kıyasen olacağı açıktır.

Türk-İsviçre hukukunda inançlı işlemin amacına göre yapılan bu ayrımın yanı sıra Alman hukukunda inanılanın malı veya hakkı inanan yararına devraldığı ve inanç konusunu inanan yararına idare etmesine yönelik inançlı işlem (Erwerbstreuhand); mal veya hak sahibinin inanç sözleşmesi ile bu mal veya hakkı inanan menfaatine idare etmeyi yükümlenmesine yönelik inançlı işlem (Vereinbarungstreuhand); son olarak inananın malvarlığındaki malı veya hakkı inanılana devretmesine yönelik inançlı işlem (Übertragungstreuhand)'den bahsedilmektedir ${ }^{19}$. Malın veya hakkın teminat amacıyla inançlı temliki ile benzerlik gösteren inançlı devir (Übertragungstreuhand) halinde, Türk-İsviçre hukukundan farklı olarak bu inançlı devir işlemiyle birlikte malın hukuki anlamda malikinin inanılan olduğu ancak iktisadi anlamda mülkiyetin inanan yani devredende kaldığı ifade edilmektedir. Mülkiyetin devrinde bu şekilde bir ayrım hukuk sistemimizde kabul edilmemiş olup, daha sonra inceleneceği üzere, hem doktrin hem de uygulamada inançlı temlikte tam hak devri teorisi neredeyse istisnasız olarak kabul edilmektedir.

14 Jäggi / Gauch / Hartmann, Art. 18, N 202; esas sermaye payının teminat amaçlı inançlı temlikinin kendi yararına inançlı işlem teşkil ettiği yönünde bkz. Mühl, O., "Der Geschäftsanteil in einer Gesellschaft mit beschränkter Haftung als Kreditsicherheit (treuhänderische Übertragung, Verpfändung, Nießbrauch)”, Gesellschaftsanteile als Kreditsicherheit, Duncker $\$$ Humboldt, Berlin 1979, s. 144.

15 Özsunay, İnançlı Muameleler, s. 57.

16 Saf inançlı işlemler ile karma inançlı işlemler arasındaki bu farklılık inanç ilişkisinde özellikle inananın korunması ve tarafların iflası noktasında önem arz etmektedir. Bu farklılıklara ilgili başlıklar altında değinilecektir.

17 Tandoğan, İnançlı İşlemler, s. 75; Özsunay, E., "Saf İnançlı Muamelelerde Vekalet Sözleşmesine İlişkin Hükümlerin Uygulanması", Temsil ve Vekalete İlişkin Sorunlar, Sempozyum, İstanbul 1977, (s. 99-125) s. 101 vd.; Altaş / Kurt, s. 8.

18 Aydıncık, s. 171 vd.; Altaş / Kurt, s. 9; Özsunay, İnançlı Muameleler, s. 137 vd.; Oktay-Özdemir, s. 277. Eren, inanç işleminin hukuki niteliğini tespit ederken inançlı işlemler arasında bir farklılığa değinmeksizin tüm inançlı işlemler için inanç anlaşmasının hukuki niteliğinin kendine özgü bir sözleşme olduğunu ifade etmiştir. Bu sözleşmeye vekâlete ilişkin hükümler kıyasen uygulanacaktır. Bkz. Eren, Borçlar Hukuku Genel Hükümler, s. 384.

19 Armbrüster, C., Die treuhänderische Beteiligung an Gesellschaften, Carl Heymanns Verlag, 2001, s. 15. 
Teminat amaçlı inançlı temlik bir eşyayı konu edinebileceği gibi, bir hakkın da inançlı temliki söz konusu olabilir. Bu durum mülkiyetin teminat amaçlı devri (Sicherungsübertragung) ve alacağın teminat amaçlı devri (Sicherungszession) olarak ifade edilir ${ }^{20}$. Daha önce bahsedildiği üzere esas sermaye payının rehni bir hak rehnidir; bu nedenle esas sermaye payının inançlı temlikinde de bir hakkın inançlı temliki söz konusu olur ${ }^{21}$. İnançlı temlikin inanç konusunun türüne göre yapılan ayrımda esas sermaye payının inançlı temliki alacağın inançlı temliki olarak ele alınabilirse de alacağın temlikinden ayrılan yanları olduğu; alacağın temlikine ilişkin hükümlerin bu işlemde kıyasen ve bünyesine uygun olduğu ölçüde uygulanması gerektiği ifade edilmelidir ${ }^{22}$.

Limited şirket esas sermaye payının inançlı temlikinde saf inançlı işlemin söz konusu olması mümkündür. Özellikle genel kurulda oy hakkının da kullanılmasını sağlamak için idare amacıyla esas sermaye payının devri mümkündür. Bu durumda inanılan (payı devralan, yeni ortak) inananın (payı devreden, eski ortak) menfaati doğrultusunda işlem yapar ve onun talimatlarıyla bağlıdır. Ayrıca esas sermaye payının bir üçüncü kişi yararına elde bulundurmak üzere devralınması (Erwerbstreuhand) ve limited şirket ortağının üçüncü kişiyle yapacağı inançlı işlemden sonra esas sermaye paylarını o kişi yararına elinde bulundurması (Vereinbarungstreuhand) söz konusu olabilir. Ancak çalışmamızda inceleme konusu yapılacak kısım karma inançlı işlem olan esas sermaye payının teminat amaçlı inançlı temlikidir. Bu nedenle esas sermaye payının teminat amaçlı inançlı temliki dışında kalan ve esas sermaye payını konu alan diğer inançlı işlem türleri üzerinde bir inceleme yapılmamıştır.

\section{Esas Sermaye Payının İnançı Temlikinde Güdülen Amaç}

Esas sermaye payının rehni yerine inançlı işlem yoluyla teminat amaçlı devrinin birden fazla sebebi olabilir $^{23}$. Esas sermaye payının rehninde, teminat altına alınan alacağın ödenmemesi halinde esas sermaye payının satılması ve satım bedelinden alacağın tahsil edilmesi söz konusu olmaktadır. Esas sermaye payının teminat amacıyla inançlı temliki bu uzun ve karmaşı sayılabilecek prosedürü ortadan kaldırmaktadır. Esas sermaye payının bu şekilde paraya çevrilmesini, borçlunun aleyhine olabilecek sonuçları engellenmiş olmaktadır. Bu şekilde inanılana, teminat sağlamayı amaçlayan olağan hukuki işlem olan rehinden daha güçlü bir konum sağlanmaktadır ${ }^{24}$. Bu sayede teminat konusunun inançlı temliki sayesinde teminat alan (inanılan) rehin hakkının sağlayacağından daha

20 Kramer/Schmidlin, Art. 18 Nr. 21; Müller, K./ Gruber, U., Sachenrecht, Vahlen Verlag, 2016, Art. 18, Nr. 411.

21 Serick, R., Eigentumsvorbehalt und Sicherungsübertragung: Neue Rechtsentwicklungen, 2. Auflage, Heidelberg 1993, s. 26; Altaş / Kurt, s. 4.

22 Alacağın teminat amaçlı inançlı temlikinde üç sözleşme vardır: İlki alacağın devri işlemi (Abtretungsvertrag), ikincisi inanç sözleşmesi (Sicherungsvertrag), üçüncüsü ise inanç konusu alacağın doğumuna yol açan sözleşme, genelde ödünç veya satım sözleşmesi. bkz. Nörr / Scheyhing / Pöggeler, s. 138. Esas sermaye payının inançlı temlikinde ise alacağın doğumuna yol açan sözleşmeden bahsedilemez; esas sermaye payı hem hak hem de borçları bünyesinde ihtiva eden bir bütündür.

23 Teminat amaçlı inançlı temlikin avantaj ve dezavantajlarına toplu bir bakış için bkz. Oktay-Özdemir, s.267-269.

24 Kocayusufpaşaoğlu / Hatemi / Serozan / Arpacı, $\$ 35$, Nr. 37; Esener, Muvazaalı Muameleler, s. 155; Armbrüster, C., “Treuhänderische GmbH-Beteiligungen (I) Begründung, Übertragung, Umwandlung, Beendigung”, GmbHR 2001, (s. 941-950) s. 944; Mühl, s. 144; Baumbach, A. / Hueck, A. / Servatius, W., Gesetz betreffend die Gesellschaften mit beschränkter Haftung, 21. Auflage, C. H. Beck, 2017, § 15, Nr. 49 vd.; Altaş / Kurt, s. 9. Yarg. 14. HD 14.3.2019, E. 2016/16087, K. 2019/2373. Karar için bkz. http://www.karararama.yargitay.gov.tr (erişim tarihi: 03.12.2019). 
geniş bir güvence elde etmekte, rehnin paraya çevrilmesi esnasında karşılaşılacak prosedürel zorluklar ve paraya çevirmede meydana gelebilecek değer eksilmesi kural olarak söz konusu olmaz ${ }^{25}$. Ayrıca üzerinde rehin hakkı tesis edilen eşya veya hak, rehin borçlusunun iflası halinde iflas masasına dahil olur, rehin alacaklısı ise eşya veya hakkın satımından elde edilen tutar üzerinde rüçhan hakkını haiz olur. Ancak inançlı temlik halinde işlem konusu artık inanılanın malvarlığına dâhil olduğu için, inanan iflas ettiği takdirde rehinli mal/hak iflas masasına dahil olmayacaktır. Dolayısıyla teminat amacıyla inançlı temlik uygulamada sıklıkla karşılaşılan bir yöntem olarak karşımıza çıkmaktadır.

Limited şirket esas sermaye payının rehni yerine teminat sağlama amacıyla inançlı temlikinin tercih edilmesinin en önemli sebebi ise şudur: Esas sermaye payının rehnedilmesi halinde rehin alacaklısı yalnızca rehnin paraya çevrilmesini talep etme hakkını haiz olacaktır. Bunun dışında rehin, rehin alacaklısına bir hak tanımamaktadır. Esas sermaye payının inançlı temliki halinde ise inanılan limited şirket ortağı olacaktır. Bu nedenle esas sermaye payından kaynaklanan tüm hakları haiz olacaktır $^{26}$. Bu şekilde inanılan yönetsel hakları kullanmak suretiyle kendi menfaatini korurken mali haklardan istifade suretiyle alacağını da şirketten tahsil edebilir. Esas sermaye payının inançlı temlikinin teminat alan açısından bir diğer faydası da artık ortak sıfatını haiz olacağı için oy hakkını onun kullanacak olmasıdır. Elbette ki esas sermaye payı rehninde rehin alacaklısını korumaya yönelik oy sözleşmeleri yapılabilir. Ancak bunlar rehin alanı korumak için yetersiz kalabilmektedir. Rehin veren ortak her zaman genel kurulda alınacak kararlar ile esas sermaye payının değerini düşürmeye yönelik eylemlerde bulunabilir. Her ne kadar bu eylemler bir tazminat yükümlülügüne yol açacaksa da rehin alacaklısının korunmasının temin edildiği söylenemez. Ayrıca rehin hakkı tesis edilmesi halinde ortağın çıkarılması veya esas sermaye payının itfası hallerinde zarara uğraması ihtimali inançlı temlikinden daha yüksektir.

Esas sermaye payının rehni yerine inançlı temlikinin tercih edilmesi beraberinde birtakım dezavantajları da getirmektedir. Öncelikle esas sermaye payının inançlı temlik yoluyla devralınması esas sermaye payından kaynaklanan yükümlülüklerin de üstlenilmesi anlamına gelmektedir ${ }^{27}$. Bunun yanı sıra esas sermaye payını inançlı temlikle devralan inanılan, yeni ortak olarak ticaret siciline tescil ve pay defterine kaydedilmektedir. Bu durum 6183 sayılı Amme Alacaklarının Tahsili Usulü Hakkında Kanun ${ }^{28} 35$ uyarınca amme alacaklarından da sorumlu olması sonucunu doğurur. Devralan ortağın bu sorumluluğu AATUHK 35/II uyarınca devirden önceki dönemi de kapsar; devralan, bu dönem borçlarından devredenle birlikte müteselsilen sorumlu olmaktadır.

25 Rehnin paraya çevrilmesi prosedüründe alacaklının esas sermaye payını belirlenen asgari satış bedeli üzerinden alacağa mahsuben alması ve eksik kalan tutar için borçluyu haciz yoluyla takibe devam etmesi halinde toplam alacağından daha yüksek değerde bir tahsilat yapması mümkündür.

26 Armbrüster, Die treuhänderische Beteiligung an Gesellschaften, s. 39.

27 Armbrüster, Die treuhänderische Beteiligung an Gesellschaften, s. 43; Fleischer, H. (Hrsg.) / Goette, W. (Hrsg.) / Reichert, J. / Weller, M. P., Münchener Kommentar zum Gesetz betreffend die Gesellschaften mit beschränkter Haftung (GmbHG), 2. Auflage, C. H. Beck, 2015, § 15, Rn. 275; Roth, H., "Pfändung und Verpfändung von Gesellschaftsanteilen”, ZGR 2000, (s. 187-222) s. 219. 
Esas sermaye payının rehni yerine inançlı temlikinin bir diğer dezavantajı ise, özellikle inanan bakımından doğmaktadır. Devreden, yani inanan, şirketteki ortak sıfatını yitirmektedir ${ }^{29}$. Esas sermaye payı inançlı temlik işlemiyle birlikte artık yeni ortağın malvarlığında yer alacağı için inanılanın alacaklıları bu esas sermaye payı üzerinde haciz işlemi yaptırabilecekleri gibi, inanılanın iflas etmesi halinde esas sermaye payı iflas masasına dâhil olur. Bu durumda inanan devrettiği esas sermaye payını iflas masasından çıkarması mümkün olmaz veya esas sermaye payı üzerinde bir istihkak iddiası ileri süremez.

Esas sermaye payının inançlı temlikinde söz konusu olacak başka bir dezavantaj devir sürecinde ortaya çıkar. Esas sermaye payı üzerinde rehin kurulabilmesi için genel kurulun onayı, ancak bu durum şirket sözleşmesinde öngörüldüyse söz konusu olur (TTK 600/II). Buna karşılık esas sermaye payı devrinde kural genel kurul onayının alınmasıdır; bu onay şartı şirket sözleşmesiyle kaldırılabilir (TTK 595/II). Dolayısıyla esas sermaye payının inançlı temlik ile devrinde, şirket sözleşmesiyle devre ilişkin ayrı bir düzenlemeye yer verilmedikçe, genel kurul onayı aranır ki, bu onayı almak her zaman kolay olmayabilir.

\section{Esas Sermaye Payının İnançlı Temlik ile Devredilmesine Yönelik İşlemler}

\section{a. Inanç Sözleşmesi}

Bir hakkın inançlı temlikine ilişkin inanç sözleşmesinde inanan, hakkın sahipliğini inanılana tam olarak devretmeyi, inanılan da devraldığg hakkı bu sözleşmeye uygun olarak idare etmeyi ve birtakım şartların gerçekleşmesi halinde inanana iade etmeyi yükümlenir ${ }^{30}$. Teminat amacıyla yapılan inançlı işlemde bu şart çoğu zaman teminat altına alınan borcun ödenmesidir. Esas sermaye payının teminat amaçlı inançlı temliki, esas sermaye payı devri teşkil eder ve limited şirket ortaklık yapısında farklılık meydana getirir. Her ne kadar bu işlemin amacı devralana teminat sağlamak olsa da özünde esas sermaye payının devrini teşkil eder. Dolayısıyla bu işlem esas sermaye payının devrini düzenleyen TTK 595 hükmüne uygun olarak gerçekleştirilmelidir.

İnançlı temlik işleminin kendisi bir tasarruf işlemi olmasına rağmen, inançlı temlike dair taahhüt aşaması da mevcuttur ${ }^{31}$. Uygulamada her ne kadar taahhüt ve tasarruf işlemleri aynı anda gerçekleştirilmekteyse de teorik olarak öncelikle taahhüt işleminin incelenmesi doğru olur. Bu aşamada taraflar ${ }^{32}$ arasında yapılan sözleşme "inanç sözleşmesi” (fiduziarisches Grundgeschäft /

29 Reichert / Weller, MüKoGmbHG, \$ 15, Rn. 275.

30 Esener, Borçlar Hukuku I, s. 108; Altaş/ Kurt, s. 4; Yarg. 14. HD, 1.3.2007, E. 726/2007, K. 2065/ 2007; HGK, 14.07.2010, E. 14-394/ 2010, K. 395/ 2010; Yarg. 1. HD, 30.10.2000, E. 12988/2000, K. 13223/ 2000; bahsedilen karar için bkz. www. kazancı.com.tr (erişim tarihi: 01.10.2016).

31 Aydıncık, s. 161 vd.; Tandoğan, "İnançlı İșlem”, s. 74; Özsunay, İnançlı Muameleler, s. 85 vd.; Oğuz, A., "Roma Ve Türk Hukukunda İnançlı İşlem Ve Vekalet Sözleşmelerinin Karşılaştırılması”, AÜHFD 1989-1990, S. 1-4, (s. 225-284) s. 239240; Uygur, A., Teminat Amaçlı İnançlı İşlemler, Gazi Üniversitesi Hukuk Fakültesi Dergisi 2006, C. X, S. 1-2, (s. 171195) s. 173; Eren, Borçlar Hukuku Genel Hükümler, s. 384; Eren, F., Mülkiyet Hukuku, 4. Bası, Yetkin Yayınları, Ankara 2016, s. 224; Esener, Muvazaalı Muameleler, s. 147 vd.; Altaş / Kurt, s. 11-12; HGK, 17.4.2010, E. 14-394/ 2010, K. 395/ 2010. [Kararın kaynağını belirtelim].

32 İnanç sözleşmesi inanan ve inanılan arasında yapılır. Esas sermaye payının başkasının borcu için teminat amaçlı 
Sicherungsabrede) olarak adlandırılır ve hem inanç konusunun inanılana kazandırılmasının hem de inançlı işlem sona erince inanç konusunun inanana iade edilmesinin hukuki sebebini teşkil eden ${ }^{33}$ bu sözleşme uygulamada taraflar arasında satım, trampa veya bağış sözleşmesi olarak nitelendirilir ${ }^{34}$. TTK 595 hükmü incelendiğinde, esas sermaye payı devri için karşımıza öncelikle esas sermaye payı devri taahhüt işlemi çıkmaktadır. Kanunda esas sermaye payı devrinin taahhüt ve tasarruf işlemi safhalarına ayrıldığı; her iki safhanın da yazılı şekil şartına tabi tutulduğu ve noter onayının arandığı görülmektedir (TTK 595/I.c.1; aynı yönde düzenleme Alman hukukunda GmbHG \$ 15/III ve IV’te yer almaktadir $\left.{ }^{35}\right)^{36}$.

TTK 595/I'in esas sermaye payı devrinin taahhüdünü dahi yazılı şekil şartı ve noter onayına tabi tutan düzenlemesi göz önüne alındığında taraflar arasındaki inanç sözleşmesinin devir borcu doğuran bir işlem olarak nitelendirilmesi ve şekil şartına tabi olup olmadığı doktrinde tartışılmıştır. Özellikle Alman hukukunda cereyan eden bu tartışmada esas sermaye payı devrinde taahhüt aşamasında ilişkin olarak GmbHG $₫$ 15/IV’te öngörülen şekil şartı amaçsal olarak ele alınmış ve esas sermaye payının inançlı temlikinin şekil şartı ile öngörülen amaç kapsamında olup olmadığ irdelenmiştir $^{37}$. Hâkim olan görüşe göre, esas sermaye payının devri usulüyle gerçekleştirilen inançlı işlemlerde taahhüt aşaması da yazılı şekle tabidir ${ }^{38}$. Zira bu halde de esas sermaye payının devri taahhüt

temlikinde de inanç sözleşmesi ortak ve alacaklı arasındadır. Dolayısıyla borçlu ile alacaklı arasındaki sözleşmenin, inanç sözleşmesi olarak adlandırılacağı görüșüne katılmıyoruz. Bu görüș için bkz. Mühl, s. 145.

33 Özsunay, "Saf İnançlı Muameleler", s. 112; Tandoğan, Özel Borç İlişkileri, s. 546; Antalya, Borçlar Hukuku Genel Hükümler C. V/ 1,1, § $15 \mathrm{~N} 1533$.

34 Tandoğan, İnançlı İşlem, s. 76; Jäggi/ Gauch/ Hartmann, Art. 18, N. 210-211. İnanç sözleşmesinin bu şekilde nitelendirilmesi, bu sözleşmenin geçersizliği sonucunu doğurmayacağ gibi, muvazaalı işlem olduğu anlamına gelmez. Burada tarafların sözleşmeyi yanlış nitelendirmeleri söz konusudur. Bkz. Jäggi / Gauch / Hartmann, Art. 18, N. 213; Kramer / Schmidlin, Art. 18 Nr. 125 ve 131; Guhl / Koller / Schnyder / Druey, \$15, N. 28.

35 BGH, Beschluß vom 8. 5. 2007 - VIII ZR 235/06 (OLG Frankfurt a.M.).

36 Taahhüt işleminin şirket sözleşmesiyle genel kurul onayına bağlanabileceği yönünde bkz. Verse, GmbHG $\$ 15$, Rn. 124.

37 Belirtilmelidir ki, Alman hukukunda esas sermaye payını konu alan inançlı işlemler, "esas sermaye payının inanan yararına devralınmasına yönelik inançlı işlem" (Erwerbstreuhand); "ortağın inanç sözleşmesi ile birlikte bundan sonra esas sermaye payını inanan menfaatine idare etmeyi yükümlendiği sözleşme inançlı işlemi" (Vereinbarungstreuhand); son olarak, "ortağın esas sermaye payını inanılana devrettiği inançlı devir" (Übertragungstreuhand) olarak üçe ayrılmaktadır. Bahsedilen tartışma bu inançlı işlem türlerinden hangilerinin taahhüt işleminin yazılı şekil şartına tabi olduğuna dairdir. Benzeri bir ayrım Türk-İsviçre hukukunda yapılmadığı için tartışmanın "Vereinbarungstreuhand" ve "Erwerbstreuhand" işlemlerine ilişkin kısımlarına yer verilmesi gereksiz görülmüştür. Nitekim Alman hukukunda dahi bunların gerçek inanç ilişkisi olmadığı (unechtes Treuhandverhältnis) yönünde görüşler mevcuttur. Bu görüş hakkında bilgi için bkz. Armbrüster, "Treuhänderische GmbH-Beteiligungen”, s. 941 ve dn.3-5. Yine de bu kapsamda değerlendirilip, aslında bir pay devrinin dahi gerçekleșmediği, mevcut ortağın esas sermaye payını artık üçüncü kişi (inanan) yararına elinde bulundurmayı taahhüt ettiği "Vereinbarungstreuhand"da dahi, genel kurul onayının şirkete dişarıdan yapılacak etkileri kontrol altında tutmak olduğu gerekçesiyle genel kurul onayına tabi olduğu ifade edilmiştir. Bkz. Schmidt, s. 1045; Armbrüster, Die treuhänderische Beteiligung an Gesellschaften, s. $117 \mathrm{vd.}$

38 Lutter, M. / Hommelhof, P. / Bayer, W. / Kleindiek, D., GmbH-Gesetz, 19. Auflage, Otto Schmidt Verlag, 2016, § 15, Rn. 105; Michalski, L. (Hrsg.) / Heidinger, A. (Hrsg.) / Leible, S. (Hrsg.) / Schmidt, J. (Hrsg.) / Ebbing, F., Kommentar zum Gesetz betreffend die Gesellschaften mit beschänkter Haftung (GbmH-Gesetz), 3. Auflage, C.H. Beck, 2017, $\$ 15$, Rn. 209; Baumbach / Hueck / Servatius, \$ 15, Nr. 56; Reichert / Weller, MüKoGmbHG, \$15, Rn. 211 vd.; Wicke, H., GmbHG, 3. Auflage, C. H. Beck, 2016, \$15, Rn. 31; Gehrlein, M. (Hrsg.) / Born, M. (Hrsg.) / Simon, S. (Hrsg.) / Winter, S., GmbHGKommentar, 3. Auflage, Carl Heymanns Verlag, 2017, $\$ 15$, Rn. 98; Bork, R. (Hrsg.) / Schäfer, C. (Hrsg.) / Brandes, S., GmbHG - Kommentar zum GmbH-Gesetz, 3. Auflage, Köln 2015, \$ 15, Rn. 62; esas sermaye payının devrini konu alan inanç sözleşmesinin şekle tabi olduğu, ancak limited şirketin henüz kurulmadığı ve inanç sözleşmesinin şirketin ticaret 
edilmiş olmaktadır. Aksi yöndeki görüşş ${ }^{39}$ göre ise, esas sermaye payının inançlı temliki halinde esas sermaye payının "hukuki mülkiyeti" inanılana geçmekteyse de "ekonomik mülkiyeti" devredende kalmaktadır ${ }^{40}$. İnanç sözleşmesi kalııı bir değişikliği amaçlamamaktadır. İnanç sözleşmesi yalnızca hukuki mülkiyet ile ekonomik mülkiyeti birbirinden ayırmaya yarayan bir hukuki araç olup, GmbHG \$15/IV’te taahhüt işlemi için öngörülen şekil şartı yalnızca esas sermaye payının spekülatif devrinin önlenmesini amaçlamaktadır ${ }^{41}$. Tasarruf işlemi için öngörülen şekil şartının aksine burada kanun koyucu tarafların korunmasını amaçlamamaktadır. Düzenlemenin spekülatif işlemleri engellemeye yönelik amacı ve esas sermaye payının inançlı temlikinin payın ekonomik anlamda sahibini değiştirmeyeceği dikkate alındığında, esas sermaye payının inançlı temlikine yönelik inanç sözleşmesinin GmbHG $₫$ 15/IV (TTK 595/I.c.1)'deki şekil şartına tabi olmayacağı sonucuna varılmaktadır.

Yukarıda ifade edilen ikinci görüş Türk hukuku bakımından kabul edilemez. Zira Türk hukukunda mülkiyetin hukuki / ekonomik olarak ayrımı söz konusu değildir ${ }^{42}$. Aynı şekilde hakkın şekli / hukuki veya maddi / iktisadi olarak ayrılması da mümkün değildir. Benzer durum İsviçre hukuku için de geçerlidir ${ }^{43}$. Esas sermaye payının inançlı temlikinde yeni ortak, esas sermaye payını devralan olmaktadır. Esas sermaye payı ve ondan kaynaklanan tüm hak ve yükümlülükler devralana geçmektedir. Devredenin, esas sermaye payı üzerinde devam etmekte olan "ekonomik mülkiyet"inden bahsedilemez. İnanılanın teminat konusu esas sermaye payını elinde bulundurduğu sürece inananın menfaatlerini de göz ardı etmemesi gerektiği ve aralarındaki inanç sözleşmesine uygun hareket etmesi gerektiği aşikârdır. Ancak bu durum devreden inananın esas sermaye payı üzerinde hak sahibi olduğu anlamına gelmez.

siciline tescili şartına bağlandığı halde şekil şartı aranmayacağı yönünde karar için bkz. SG Kassel, Urteil vom 17.05.2017 - S 12 KR 436/15, Rn. 32.

39 Lieder, J./ Villegas, D., "Treuhandverträge über GmbH-Geschäftsanteile - eine Frage der Form?”, GmbHR 2018, (s. 169-177), s. 170-173; Armbrüster, Die treuhänderische Beteiligung an Gesellschaften, 104; Armbrüster, C., "Zur Beurkundungsbedürftigkeit von Treuhandabreden über GmbH-Anteile - Zugleich ein Beitrag zu den Formzwecken des $\$ 15$ Abs. 4 Satz 1 GmbHG-”, DNotZ1997, (s.762-786) s. 779 vd.; Armbrüster, “Treuhänderische GmbH-Beteiligungen”, s. 946.

40 Esasen bu görüşün sebebi Alman hukukunda inançli temlik halinde "tam hak devri" teorisinin değil "şekli hukuki durum teorisi" veya "şekli hak sahipliği teorisi”nin kabul edilmesidir. Şekli hukuki durum teorisi, inanç konusu üzerindeki hakkı, hukuki-iktisadi olarak ayırmaktayken, şekli hak sahipliği teorisine göre inançlı temlik halinde hakkın kendisi değil, o hakkı kullanma yetkisi devredilmektedir. Her iki teori de Türk-İsviçre hukukunda kabul görmemiştir. Bkz. Özsunay, İnançlı Muameleler, s. 163 vd.

41 Altmeppen / Roth, $\$ 15$, Rn. 66; Lutter / Hommelhof / Bayer / Kleindiek, $\$ 15$, Rn. 12; Reichert / Weller, MüKoGmbHG, \$15, Rn. 16; Armbrüster, "Beurkundungsbedürftigkeit von Treuhandabreden über GmbH-Anteile", s. 762, s. 767 vd.; Baumbach / Hueck / Servatius, \$15, Nr. 20; Eckhart, D. (Hrsg.) / Hermanns, M. (Hrsg.), Kölner Handbuch Gesellschaftsrecht, Carl Heymanns Verlag, 2017, KölnerHdbGesR, § 2, Rn. 871; Hirte, H., Kapitalgesellschaftsrecht, 8. Auflage, RWS Verlag, Köln 2016, s. 309, Rn. 4.55; Winter, \$15, Rn. 31; Priester, H. (Hrsg.) / Mayer, D. (Hrsg.) / Wicke, H. (Hrsg.) / Jasper, D. / Wollbrink, S., Münchener Handbuch des Gesellschaftsrechts, Band: 3, Gesellschaft mit beschränkter Haftung, 5. Auflage, 2018, \$24, Rn. 30.

42 Tandoğan, “İnançlı İşlem”, s. 81 vd.; Tandoğan, Özel Borç İlişkileri, s. 550; Özsunay, İnançlı Muameleler, s. 163 vd.

43 Tandoğan, "İnançlı İşlem”, s. 79; Merz, s. 457. 
Nihayetinde kanaatimizce esas sermaye payının inançlı temlikini konu alan inanç sözleşmeleri de yazılı olmalı ve imzaları noter tarafından onaylanmalıdır ${ }^{44}$. İfade etmeliyiz ki bu hususta Alman doktrininde ileri sürülen şekli / hukuki hak ayrımını kabul etmediğimiz gibi, Yargıtay’n inanç sözleşmesinin geçerliliği için yazılı delil arayan görüşüne de katılmıyoruz ${ }^{45}{ }^{46}$. Her ne kadar kanun koyucu inanç sözleşmesini düzenlememiş ve dolayısıyla bir şekil şartı da öngörmemişse de esas sermaye payını konu alan inanç sözleşmesinin onun devri borcunu yüklediği göz önüne bulundurularak TTK 595/I hükmü uyarınca yazılı ve noter tarafından onaylı olarak akdedilmesi geçerlilik şartı olarak kabul edilmelidir. Nitekim esas sermaye payının devrinin inançlı olarak gerçekleştirilecek olması, bu işlemin esas sermaye payının devri borcunu doğurduğu gerçeğini değiştirmemektedir.

İnanç ilişkisi kurulduktan sonra inanan, esas sermaye payının iadesine yönelik talep hakkını başkasına devredebilir. Kanaatimizce bu halde de değişikliğe ilişkin işlem şekle tabidir; zira burada

44 Arslanl, H./ Domaniç, H., Türk Ticaret Kanunu Şerhi, C. III, Limited Şirketler Hukuku Ve Uygulaması, Hisseli Komandit Şirketler, İstanbul 1989, s. 273. İnanç sözleşmesinin yazılı olması esas sermaye payının inançlı temliki açısından bir geçerlilik şartı olduğu gibi, inanç konusunun böyle bir geçerlilik şartı gerektirmemesi halinde dahi ispat kolaylığı açısından yazılı yapılması faydalı olacaktır. Aynı yönde bkz. Yasaman, Hisse Devri, s. 584. HMK 200 uyarınca hukuki işlemin değerinin 2020 yılı itibariyle 4.486,428 TLyi aşması halinde senetle ispat zorunluluğu söz konusu olacaktır (VUK Mükerrer 298, Vergi Usul Kanunu Genel Tebliği Sıra No: 512).

45 Kanun koyucu tarafından düzenlenmemiş olan inanç sözleşmesi için bir şekil şartı söz konusu olmamakla birlikte Yargıtay özellikle tapu iptali ve tescile ilişkin uyuşmazlıklara dair vermiş olduğu kararlarında inanç ilişkisinin ispatı için yazılı delil aranmakta, yazılı delil mevcut değilse delil başlangıcının varlığı halinde tanık deliline dayanılabileceğini ifade etmektedir. bkz. Kılıçoğlu, s. 247. Y. YİBK, 05.02.1947, 20/6; “Uygulamada mesele, 05.02.1947 tarihli, 20/6 sayılı İnançları Birleştirme Kararı ile ilişkilendirilip, bu karar dayanak yapılmak suretiyle çözüme gidilmektedir. İçtihadı Birleştirme kararının sonuç bölümünde ifade olunduğu üzere, inançl işleme dayalı olup dinlenilirliği kabul edilen iddiaların ispatı, şekle bağh olmayan yazılı delildir. İnanç sözleşmesi olarak adlandırılan bu belgenin, sözleşmeye taraf olanların imzasını içermesi gereklidir." Y. 1. HD, 19.06.2019, E. 8019/2016, K. 3930/ 2019; Y 1. HD, 25.06.2019, E. 3737/ 2016, K. 4074/ 2019. Yazılı delilin mevcut olmaması halinde (yazılı) delil başlangıcına dayanılabileceği yönünde karar metninin ilgili kısmı şu şekildedir: "Bilindiği üzere; inançlı işlem iddialarının 05.02.1947 tarihli 20/6 sayılı İçtihadı Birleştirme Kararı uyarınca, şekle bağh olmayan yazılı delille kanıtlanması gerekeceği; böyle bir belgenin yokluğu sebebiyle inançlı işlem iddiası kanıtlanamıyorsa, delil başlangıcı sayılacak nitelikteki bir olgunun varlığı halinde buna itibar edilmesi gerekeceğ $i$ tartışmasızdır. Şayet, T.M.K'nun 6. maddesi hükmü uyarınca ispat külfeti kendisinde olan tarafin yazılı bir belgesi yok ise ancak taraflar arasında gerçekleştirilen mektup, banka dekontu, yazışma, gibi birtakım belgeler var ise ancak bunların delil başlangıcı sayılacağı ve iddianın tanık dahil her türlü delille kanıtlanmasının olanaklı hale geleceği açıktır. Eğer böylesi bir delil başlangıcı sayılacak bir olgu da bulunmuyor ise iddia sahibinin son başvuracağı delilin karşı tarafa yemin teklif etme hakkı olduğu şüphesizdir.” Yarg. 1 HD, 18.04.2019, E. 1073/ 2019, K. 2827/ 2019; Yarg. 14. HD, 2.4.2019, E. 16634/ 2016, K. 2997/ 2019; Yarg. 14. HD, 3.12.2018, E. 9912/ 2016, K. 8503/ 2018; Yarg. 14. HD, 18.12.2018, E. 3145/ 2018, K. 9161/ 2018; Yarg. 14. HD, 25.3.2019, E. 5707/ 2018, K. 2692/ 2019; Yarg. 14. HD, 6.2.2019, E. 11260/ 2016, K. 991/ 2019; Yarg. 14. HD, 22.1.2019, E. 5500/ 2016, K. 658/ 2019; Yarg. 14. HD, 19.12.2018, E. 10116/ 2016, K. 9215/ 2018; Yarg. 14. HD, 17.12.2018, E. 9895/ 2016, K. 9067/ 2018; Yarg. 14. HD, 26.11.2018, E. 8996/ 2016, K. 8242/ 2018; bahsedilen kararlar için bkz. http://www.karararama.yargitay.gov.tr (erişim tarihi: 03.12.2019).

46 Yargıtay İBK kararıyla aynı doğrultuda vermiş olduğu bir kararda, esas sermaye payının inançlı temlikine ilişkin borçlandırıcı işlemin noter onaylı olmaması nedeniyle geçersiz olduğu yönündeki ilk derece mahkemesi kararını bozmuştur. Yarg. 11. HD, 21.02.2017, E. 1835 / 2016, K. 986 / 2017 (Karar için bkz. Lexpera İçtihat Bankası, erişim tarihi: 3.12.2019; Karar ayrıca BATIDER, 2017, C. XXXIII, S. 2, s. 288'de yayınlanmıştır.). Kanunda öngörülen şekle uygun yapılmayan inanç sözleşmesini takiben gerçekleştirilen esas sermaye payı devrinde, devredenin inanç sözleşmesinin geçersizliğini bilseydi devir işlemini gerçekleştirmeyeceğine ilişkin iddiasının dinlenmeyeceği yönünde karar için bkz. BGH, Urt. v. 22.9.2016 - III ZR 427/15 (OLG Schleswig). 
devir borcu doğuran bir işlem söz konusudur ${ }^{47}$. Aksi kabul, TTK 595/I ile önlenmek istenen esas sermaye payının devri taahhüdünün şekle tabi olmaksızın gerçekleştirilebilmesine yol açar.

\section{b. Devir Işlemi}

Esas sermaye payının devri vaadi niteliğindeki inanç sözleşmesinin kanunda öngörülen şekle uygun yapılmasından sonra devreden, yani inanan ortağın esas sermaye payını devretme borcu doğar. Bu borcun yerine getirilmesi için gerçekleştirilecek esas sermaye payı devri tıpkı normal bir esas sermaye payı devri ile aynı usule tabidir, bir farklılık arz etmez ${ }^{48}$. Bu nedenle esas sermaye payının devri şirket sözleşmesiyle yasaklanmışsa bu yasak esas sermaye payının inançlı temliki için de geçerlidir ${ }^{49}$. Esas sermaye payı üzerinde rehin hakkı tesis edilmesinin genel kurul onayına tabi kılınmadığı ve devir işleminin inançlı temlik niteliğinde olduğu gerekçesiyle genel kurul onayı aranmayacağı savı yerinde olmaz.

Esas sermaye payı üzerinde tasarruf işlemini gerçekleştirmek için yazılı devir sözleşmesinin noter tarafından imzalarının onaylanması gerekir. Ardından şirket sözleşmesinde aksi düzenlenmedikçe bu devir için genel kurulun onayı gerekir. Esas sermaye payını devreden ortak da bu toplantıya katılıp oy kullanabilir ${ }^{50}$.

Aynı usul inanç ilişkisinin sona ermesinin ardından esas sermaye payının eski ortağa iadesinde de geçerlidir. Esas sermaye payının ilk devrinde genel kurul onay verirken bu devrin inanç sözleşmesi nedeniyle gerçekleştirildiği bilse dahi iade esnasında tekrar genel kurul onayı alınması gereklidir ${ }^{51}$. Genel kurulun devre onay vermemesi halinde o ana kadar askıda olan devir işlemi kesin hükümsüz olur $^{52}$. Genel kurulun ret kararına karşı iptal davası açılması mümkündür. Nitekim her ne kadar genel kurul ret için haklı sebep göstermek zorunda değilse de (TTK 595/III) bu kararın eşitlik ilkesi

47 Alman hukukunda inanılan değişikliği sonucunu doğuran devrin şekle tabi olmadığı görüşü hakimdir. Bkz Altmeppen / Roth, $₫ 15$, Rn. 48; Verse, GmbHG $\$ 15$, Rn. 121; Winter, $\$ 15$, Rn. 101; Lutter / Hommelhof / Bayer / Kleindiek, $\$ 15$, Rn. 108; Michalski / Heidinger / Leible / J. Schmidt / Ebbing, \$15, Rn. 213; Wicke, \$ 15, Rn. 31.

48 İnanç sözleşmesinin şeklinin hakkın konusu olan şeyin şekline tabi olduğu yönünde bkz. Antalya, Borçlar Hukuku Genel Hükümler C. V / 1,1, § 15 N 1541.

49 Brandes, $\$ 15$, Rn. 61. Örneğin BRAO $\$ 59 \mathrm{e} / \mathrm{III}$ ile avukatlık ortaklığında inançlı temlik yasaklanmıştır. Benzer bir hükme avukatlık ortaklığının düzenlendiği 1136 sayılı Avukatlık Kanunu (RG, 19.3.11969, S. 13168) 44/ IV’te yer verilmemiştir. İnançlı işleme konu olan hakkın, kendi konusuna uygun olarak devredilmesi gerektiği yönünde bkz. Antalya, Borçlar Hukuku Genel Hükümler C. V / 1,1, \$15 N 1530.

50 Şener, O. H., Limited Ortaklıklar Hukuku, Seçkin Yayıncılık, Ankara 2018, s. 278, s. 337.

51 Alman doktrininde ise devir esnasında onay verilirken inançlı işlem biliniyorsa bu onayın iade işlemini de kapsadığı ifade edilmektedir. Bkz. Wicke, $₫ 15$, Rn. 31; Winter, $₫ 15$, Rn. 98; Verse, GmbHG $₫ 15$, Rn. 123; Lutter / Hommelhof / Bayer / Kleindiek, $\$ 15$, Rn. 107; Reichert / Weller, MüKoGmbHG, $₫ 15$ Rn. 219; ilk devre verilen onayın iade için geri alınamaz nitelikte olduğu yönünde bkz. Altmeppen / Roth, $\$ 15$, Rn. 50.

52 İsviçre hukukunda aynı yönde bkz. Handschin, Lukas, Geellschaftsanteile und Gesellschafterversammlung - die Willensbildung in der GmbH - die Konzernleitung der GmbH, Das neue Recht der Schweizer GmbH-Recht, Schulthess Juristische Medien AG, Zürich-Basel-Genf 2006., s. 80; Bügler, Reto, Der GmbH-Anteil Insbesondere dessen Erwerb, Übertragung und Verlust (de lege lata et ferenda), Zürich, 2004, s. 121. Alman hukukunda aynı yönde bkz. Reichert/ Weller, MüKoGmbHG, \$15, Rn. 406; Lutter/ Hommelhof/ Bayer, $\$ 15$ Rn. 89; Winter, \$15, Rn. 69; Michalski/ Heidinger/ Leible/Schmidt/ Ebbing, $\$ 15$, Rn. 156; Raiser/Veil, \$40, Rn. 15; Wicke, §15, Rn. 26. 
gözetilerek alınması gereklidir ${ }^{53}$. Genel kurulun ret yönündeki kararının iptaline ilişkin mahkeme kararı bozucu yenilik doğuran bir hüküm olup geçmişe etkilidir ${ }^{54} 55$

\section{c. Inançlı Temlik Işleminin Geçersizliği}

\section{Esas sermaye payının inançlı temliki bahsedilen şekle uygun yapılmadığı takdirde geçersiz} olacaktır ${ }^{56}$. Ayrıca esas sermaye payının alacaklılardan mal kaçırmak amacıyla inançlı temlik edilmesi halinde 2004 sayılı İcra ve İflas Kanunu ${ }^{57}$ 280/I uyarınca ilgili hükümdeki şartların da

53 İstanbul Bölge Adliye Mahkemesi 12. HD esas sermaye payı devrinde alınan genel kurul kararına ilişkin bir kararında "Bu durumda ...in pay devrine onay verilirken, aralarındaki 19.11.2015 tarihli karara dayanilarak davacinin pay devrine onay verilmemesinin eşitlik ilkesine aykırılık teşkil ettiği kabul edilemez, zira her iki ortağın hisse devri sırasındaki şartlar aynı değildir, bu durumda 7 nolu kararın iptali de doğru olmamıştır." ifadesine yer vererek eşitlik ilkesinin uygulanması için devir işlemleri sırasındaki şartların aynı olmasını aramıştır. İstanbul BAM 12 HD, T. 3.10.2019, E. 2018/1399 K. 2019/1214. (Karar için bkz. Lexpera İçtihat Bankası, erişim tarihi: 3.12.2019)

54 Poroy/ Tekinalp/ Çamoğlu, Ortaklıklar I, N 750; Poroy, Reha/ Tekinalp, Ünal/ Çamoğlu, Ersin, Ortaklıklar Hukuku II, 13. Bası, Vedat Kitapçllı, 2017, N 1715l; Moroğlu, Erdoğan, Anonim Ortaklıkta Genel Kurul Kararlarının Hükümsüzlüğü, Güncellenmiș ve Genişletilmiş 8. Baskı, On İki Levha Yayınclık, İstanbul 2017, s. 327; Bahtiyar, Mehmet, Ortaklıklar Hukuku, Güncellenmiş 14. Bası, Beta Basım Yayın, İstanbul 2020, s. 216; Kırca, İsmail/ Şehirali-Çelik, Feyzan Hayal/ Manavgat, Çağlar, Anonim Şirketler Hukuku, C. II/II, Genel Kurul Kararlarının Hükümsüzlüğü, 2. Bası, Banka ve Ticaret Hukuku Araştırma Enstitüsü, Ankara 2017, s. 254 vd. Bühren, Simon/ von der Crone, Hans Caspar, Positive Beschlussfeststellungsklage, SZW 86 (2014), (s. 564-572), s. 569.

55 Devir sözleşmesinin onayı için yapılan talebin reddine ilişkin kararın iptali, tarafları genel kurul kararının öncesindeki duruma götürür. Bir önerinin reddi şeklinde alınan limited ve anonim şirket genel kurul kararlarının iptaline dair genel bir sonuç olan bu durum taraflar açısından tatmin edici değildir. Bir önerinin genel kurul tarafından reddi hukuki durumda bir değişikliğe yol açmamakta, dolayısıyla ret kararının iptali de durumu değiştirmemektedir. İptal davası sonucunda inşai nitelikte bir hüküm kurmak mümkün olmadığından iptal kararı ile davacıya yalnızca aynı konuda ikinci bir genel kurul kararı alınması olanağı sağlanmakta ve yeni karar alındığında davacının menfaati geçen süreden ötürü zedelenmiş olabilmektedir. Buna karşın önerinin kabulüne ilişkin genel kurul kararı yeni bir hukuki durum oluşturmakta ve iptal kararı bu yeni hukuki durumu ortadan kaldırmaktadır. Bu sonucun olduğu gibi kabul edilmesi, bir önerinin reddi kararının (örneğin devrin onaylanması talebinin reddi) iptalinde menfaati bulunan ortağı, olumlu bir kararın (örneğin yönetim kurulu üyesinin seçimi) iptalinde menfaati olan ortağın bir önerinin onaylanmasında menfaati olan ortağa nazaran hukuki korumadan yoksun bırakmaktadır. Bu durumda çözüm olarak anonim şirket bağlı nama yazılı paylarının devrinde onay yetkisinin genel kurula verildiği takdirde genel kurulun hukuka aykırı kararına karşı iptal ve ifa davası açılabileceği ifade edilmektedir. Bu suretle onay kararının yönetim kurulu tarafından alındığı şirketler ile genel kurul tarafından alındığı şirketlerde pay devri açısından haksız bir fark oluşması önlenmiş olur. Akın, Murat Yusuf, Anonim Ortaklıkta Bağlı Nama Yazılı Hisseler, Vedat Kitapçllık, İstanbul 2014, s. 50 vd. Aynı sonuç esas sermaye payının devrinde genel kurul kararına ilişkin olarak da kabul edilebilir. Ayrıca Alman ve İsviçre hukukunda uygulanan, Türk hukuk doktrininde de Kırca tarafından kabul edilen "olumlu kararın tespiti davası" (positive Beschlussfeststellungsklage) açılması mümkün görülmelidir. Olumlu karar tespiti davasında mahkeme, oyların yanlış sayılması, yetkisiz kişilerin oy kullanması, öngörülenden daha yüksek nisap aranması, sadakat yükümlülüğüne aykırı oy kullanılmış olması gibi oy hesabına ilişkin hukuka aykırılıklar nedeniyle alınan ret kararı yerine, sadece matematiksel bir hesap yapmak suretiyle bu hukuka aykırılık olmasaydı şüpheye yer bırakmayacak şekilde alınacak "gerçek karar"ı belirlemektedir . Bu sayede genel kurulun olumlu kararları ile olumsuz kararlarının iptalinde söz konusu olan hukuki korumanın eksikliği giderilmiş olmaktadır. Olumlu kararın tespiti davasına ilişkin olarak Alman hukukunda Goette, Wulf (Hrsg.)/ Habersack, Mathias (Hrsg.)/ Hüffer/Schäfer, Münchener Kommentar zum Aktiengesetz, C.H. Beck, 4. Auflage, 2016, § 246 Rn. 85. İsviçre hukukunda Bühren/ von der Crone, s. 569. Olumlu tespit davasının Türk hukukunda kabul edilmesine bir engel olmadığ1 yönünde bkz. Kırca (Șehirali-Çelik/Manavgat), s. 171. 
sağlanması halinde iptal edilebilir. Bir diğer geçersizlik hali ise bu işlemin kanunun dolanılması amacıyla gerçekleştirilmesidir ${ }^{58}$.

Borçlunun aczinden veya iflasından önceki bir sene içerisinde gerçekleştirdiği bir borcu temin için yapılan rehinlerin batıl olduğu İIK 279'da düzenlenmiştir. Bu hüküm esas sermaye payının teminat amaçlı inançlı temlikinde kıyasen uygulanmalı ${ }^{59}$ ve eski ortağın aczi veya iflasından önceki bir yıl içinde gerçekleştirdiği inançlı temlik geçersiz sayılmalıdır.

\section{Esas Sermaye Payının İnançlı Temlikinin İç ve Dış ilişki Bakımından Sonuçları}

\section{a. Esas Sermaye Payının Inançlı Temlikinin Sözleşmenin Tarafları Arasındaki ilişki (İç Ilişski) Bakımından Sonuçları}

Esas sermaye payının inançlı temliki ile artık esas sermaye payı devralan-inanılanın malvarlığına dâhil olacaktır. Devralan ortak sıfatını kazanacak ve bu sıfattan kaynaklanan tüm hak ve yükümlülüklere sahip olacaktır ${ }^{60}$. İnanç konusunu teşkil eden esas sermaye payı üzerinde tek hak sahibi devralandır. Bu şahıs, esas sermaye payını dilediği gibi kullanabilir, üzerinde tasarrufta bulunabilir; esas sermaye payı üzerindeki hâkimiyeti diğer ortaklarınkinden farklılık göstermez. Dış görünüşte durum böyle olmakla birlikte taraflar arasında iç ilişkiyi düzenleyen bir inanç sözleşmesinin mevcut olduğu ve devrin bu sözleşme gereği gerçekleştirildiği unutulmamalıdır ${ }^{61}$. Taraflar aralarındaki bu sözleşmeye ahde vefa gereği uygun davranmak yükümlülüğü altındadırlar² ${ }^{62}$ Ayrıca devralan, inanç ilişkisinin devamı boyunca esas sermaye payının değerini düşürecek, ona zarar verecek işlemlerden kaçınmak zorundadır. İşte bu yükümlülük devralanın hâkimiyet alanı ile mezuniyet alanı arasında farklılığın sebebi olup, aykırılık sebebiyle 6098 sayılı Türk Borçlar Kanunu ${ }^{63} 112$ uyarınca tazminat yükümlülüğü doğar ${ }^{64}$. Ancak bu durum sözleşmeye aykırı işlemlerin geçerliliğini etkilemez. İnanılan tarafından gerçekleştirilen tasarruf işlemi tasarruf işlemi taraflarının (inanılan ve üçüncü kişi) kötüniyetli olması - ve diğer şartların da mevcudiyeti - halinde haksız fiil teşkil edebilir ${ }^{65}$. Bu durumda inanan,

58 Bormann, M. (Hrsg.) / Kauka, R. (Hrsg.) / Ockelman, J. (Hrsg.) / Schulze Steinen, M., Handbuch GmbH-Recht, 3. Auflage, Zap Verlag, 2015, §9, Rn. 169.

59 Özsunay, İnançlı Muameleler, s. 217.

60 Arslanlı/ Domaniç, s. 271; Arslanl, Limited Şirketler II, s. 191; Reichert / Weller, MüKoGmbHG, \$ 15, Rn. 223. Anonim şirket payını inançlı devralan inanılanın bu paylardan kaynaklanan rüçhan hakkının sahibi olduğu yönünde bkz. Yasaman, Hisse Devri, s. 586.

61 Arslanlı/ Domaniç, s. 271; Mühl, s. 144.

62 Kılıçoğlu, s. 249; Aydıncık, s. 132; Altaş/ Kurt, s. 3; Özsunay, İnançlı Muameleler, s. 150-151, 173; Parlak-Börü, Ş., Mülkiyetin Teminat Amacıyla İnançlı İşlemle Devri, TBB Dergisi 2017, C. 128, (s. 231 - 272), s. 242; Arslanlı / Domaniç, s. 271; Y. 14. HD, 4.3.1986, E. 5103/ 1985, K. 1412/ 1986; Jäggi / Gauch / Hartmann, Art. 18, N. 204; Winter, \$15, Rn. 94; Kramer / Schmidlin, Art. 18, Nr. 119; Guhl / Koller / Schnyder / Druey, § 15, N. 26; BGE 119 II 326, BGE 72 II 275 ; BGE 119 II 326, 328.

63 RG, 4.2.2011, S. 27836.

64 Eren, Borçlar Hukuku Genel Hükümler, s. 385-386; Özsunay, İnançl1 Muameleler, s. 151; Oktay-Özdemir, s. 270; Tandoğan, İnançlı İşlem, s. 83; Merz, s. 457; Müller, Art. 18, Nr. 414; Guhl / Koller / Schnyder / Druey, § 15, N. 29; Reichert / Weller, MüKoGmbHG, \$ 15, Rn. 231.

65 Özsunay, İnançlı Muameleler, s. 179. 
işlemin diğer tarafından da TBK 49 hükmü uyarınca uğradığı zararın giderilmesi hakkını haiz olur ${ }^{66}$. İstisnai olarak özellikle esas sermaye payının inanana zarar vermek kastıyla kötüniyetli üçüncü kişiye devrinde işlemin ahlaka aykırı olması nedeniyle geçersizliğinden söz edilebilir ${ }^{67}$, ancak bunun ispatı oldukça güçtür.

Esas sermaye payını inançlı olarak devralanın mezuniyet alanı yani yetkileri, üçüncü kişilere karşı ileri sürülebilecek şekilde sınırlandırılamaz. Eşya hukukunda tipiklik ilkesi ve borçlar hukukunda sözleşmelerin nispiliği ilkesi sınırlılık ilkesi buna engeldir. Dolayısıyla taraflar arasındaki sözleşmede yer alan kısıtlamalar dış ilişkiye yansıtılamaz ${ }^{68}$.

Esas sermaye payının teminat amaçlı inançlı temlikinin kendi yararına inançlı işlem olduğu göz önüne alındığında inanılanın menfaatinin inananınkinden daha üstün tutulması gerekir. Bununla birlikte inançlı temlikte inanan, inanılana talimat verebilir ${ }^{69}$. Yeni ortak bu talimatlara inanç sözleşmesinin amacına uygun olduğu ve kendi menfaatlerine zarar vermediği ölçüde uymak zorundadır ${ }^{70}$. Yani devredenin talimat verme yetkisinin sınırını inançlı temlik işleminin amacı çizmektedir ${ }^{71}$. Ayrıca inanan talimat verirken ortağın şirkete karşı sadakat yükümünü de göz önünde bulundurmak zorundadır. İnanan vermiş olduğu talimatlara aykırı iş ve işlemlere karşı bu işlemlerin geçersizliği sonucunu doğurmaya yönelik bir müdahalede bulunamaz ${ }^{72}$ ve talimata aykırılık bu işlemin geçersizliği sonucunu doğurmaz ${ }^{73}$. Örneğin devralan yeni ortak, oy hakkını devredenin verdiği talimata aykırı şekilde kullanırsa bu oyun geçersizliğinden söz edilemez ${ }^{74}$.

İnanç ilişkisi devamı boyunca özellikle kâr payı gibi malvarlıksal haklar esas sermaye payından kaynaklanan hak ve borçlar ortağa ait olduğu için inanılanındır ${ }^{75}$. Bununla birlikte taraflar inanç sözleşmesiyle bu esastan ayrılan bir düzenleme yapabilir. Malvarlıksal hakların, bunlar muaccel olduktan sonra ayrı bir alacak hakkı niteliğine bürünmelerinden ötürü inanana ivazsız temlik edilmesi mümkündür. Buna karşın esas sermaye payından doğan yönetsel hakların ortak sıfatını haiz olmayan inanan tarafından icra edilmesi, oy hakkında temsil yetkisi tanınması hali dışında, söz konusu değildir.

66 Altaş/Kurt, s. 19.

67 Ahlaka aykırılık sebebini belirtmemekle birlikte aynı sonuca varan görüş için bkz. Mühl, s. 146.

68 Reichert / Weller, MüKoGmbHG, \$15, Rn. 224; Jäggi / Gauch / Hartmann, Art. 18, N. 204.

69 Poroy, R. / Tekinalp, Ü. / Çamoğlu, E., Ortaklıklar Hukuku I, 13. Bası, Vedat Kitapçılık, İstanbul 2017, Nr. 772f. Talimat verme yetkisinin inanç sözleşmesinde yer almasa bile vekilin talimata aykırı hareketlerinin hukuki sonucunun düzenlendiği BGB $\$ 665$ ’ten bu sonucun çıktığı ifade edilmektedir; bkz. Reichert / Weller, MüKoGmbHG, $\$ 15, \mathrm{Rn}$. 230. Özellikle esas sermaye payı devrinin ortakların onayına bağlandığı halde devredene sınırsız talimat verme yetkisi tanıyan sözleşme hükümlerinin geçersiz olduğu yönünde bkz. Kraus, Münch.Hdb. GesR III, \$26, Nr. 45.

70 Mühl, s. 146.

71 Özsunay, İnançlı Muameleler, s. 153.

72 Özsunay, İnançlı Muameleler, s. 172.

73 Reichert / Weller, MüKoGmbHG, \$15, Rn. 227

74 Talimata aykırı kullanılan oy hakkından dolayı inananın tazminat hakkına sahip olduğu yönünde bkz. Kraus, Münch. Hdb. GesR. III, $₫ 26$, Nr. 45.

75 İnananın bu yönde nispi bir talep hakkı olacağı ifade edilmişse de biz bunun için geçerli bir gerekçe görmemekteyiz. Talimata aykırı kullanılan oy hakkından dolayı inananın tazminat hakkına sahip olduğu yönünde bkz. Kraus, Münch. Hdb. GesR. III, §26, Nr. 45. 
İnanılanın bir diğer yükümlülüğü borcun tamamen ödenmesi halinde inanç konusunu inanana iade etmektir. Bu iade yükümlülüğ̈̈ derhal doğmaktadır. Bu halde inananın iadeyi talep hakkı (Anspruch auf Rückübertragung) vardır, ancak bu hak nispi niteliktedir ${ }^{76}$.

Esas sermaye payının inançlı temlikinde tarafların karşılıklı hak ve yükümlülükleri tespit edilirken bu ilişkinin rehin tesisi yerine tercih edildiği unutulmamalıdır. Yukarıda da ifade edildiği üzere uygulanacak hükümlerde boşluk olması halinde öncelikle hak rehnine ilişkin hükümler, ardından sırasıyla taşınır rehni ve taşınmaz rehnine ilişkin hükümler kıyas yoluyla uygulanmalıdır ${ }^{77}$. Buna ilaveten ifade etmeliyiz ki inanç ilişkisi, daha önce belirtildiği üzere, bir inanç anlaşmasına dayanır. Sözleșmenin nispiliği ilkesi gereği inanç sözleşmesinden doğan talepler de nispi niteliği haizdir. Bu taleplere aynî hakka yakın bir nitelik tanımak kanaatimizce mümkün değildir ${ }^{78}$.

\section{b. Esas Sermaye Payının Inançı Temlikinin Dış îlişki Bakımından Sonuçları}

İnançlı temlikte tam hak devri teorisinin benimsenmesi sonucu inanılan artık hakkın tek başına sahibidir. Bu nedenle inanılan, esas sermaye payı üzerinde dilediği tasarrufta bulunma yetkisini haizdir. Bu tasarruflar tarafların arasındaki inanç sözleşmesine aykırı olsa dahi geçerlidir. İstisnai olarak özellikle esas sermaye payının inanana zarar vermek kastıyla kötü niyetli üçüncü kişiye devrinde işlemin ahlaka aykırı olması nedeniyle geçersizliğinden söz edilebilir ${ }^{79}$. İnançlı işlem diğer ortaklarca bilinmesine rağmen esas sermaye payının devrine olumlu oy vermelerinin, inanana karşı devam etmekte olan sadakat yükümlülügüne aykırılık teşkil edeceği ve onay talebinin reddedilmesi gerektiği ifade edilmekteyse de, inanan artık ortak sıfatını haiz olmadığı için diğer ortakların ona karşı sadakat yükümü altında olduklarından bahsedilemez ${ }^{80}$.

İnançlı işlem sayesinde inanılan hem şirket hem de üçüncü kişilere karşı tam hak sahibi ve yükümlü ortak olur. Esas sermaye payından kaynaklanan haklar ve yükümlülükler onundur ${ }^{81}$. Türk-İsviçre hukuklarında kabul edilen ve tam hak teorisi olarak adlandırılan teori uyarınca inançlı temlikle devredilen esas sermaye payı üzerindeki mülkiyet inanılana geçmekte olup, inananın bu esas sermaye payı üzerinde devam eden bir hak sahipliği söz konusu değildir. İnançlı temlike konu olan esas sermaye payının, yalnızca şekli mülkiyetinin geçtiği, gerçek hak sahibinin devreden olduğu söylenemez. Bir diğer ifadeyle inananın hala inanç konusu üzerinde bir çeşit mülkiyet hakkı sahibi

76 Özsunay, İnançlı Muameleler, s. 172; Arslanlı / Domaniç, s. 271

77 Arslanlı / Domaniç, s. 272.

78 Alman hukukunda özellikle inananın korunması amacıyla inanç ilişkisinin aynî hak benzeri sonuçları olduğu ifade edilmektedir. Bkz. Serick, Eigentumsvorbehalt und Sicherungsübertragung, s. 49.

79 Ahlaka aykırılık sebebini belirtmemekle birlikte aynı sonuca varan görüş için bkz. Mühl, s. 146.

80 Mühl tarafından ileri sürülen görüş, inançlı temlikte inananın aslında hala ortak olduğu anlayışıyla uyumlu olsa da Türk hukuku açısından kabul edilmesi mümkün değildir. Aktarılan görüş için bkz. Mühl, s. 146.

81 Schulze Steinen, Hdb. GmbHR, $\$ 9$, Rn. 173. Her ne kadar Alman hukukunda bazı yazarlar eski ortak için geçerli olan oy yasağının yeni ortak için de geçerli olduğunu, sadakat yükümlülügünün inanan için devam ettiğini ileri sürmekteyse de bu çıkarımlar Türk hukuku açısından doğru olmayacaktır. Zira bu görüşlerin temelinde de mülkiyet hakkının ikilileştirildiği teoriler yer almaktadır. Bu görüş için bkz. Raiser, T. / Veil, R., Recht der Kapitalgesellschaften, 6.Auflage, 2015, $\$ 40$, Rn. 5 . 
olduğu iddiasına gerekçe olarak gösterilen, inançlı temlik ile devredilen esas sermaye payı üzerinde inananın ekonomik mülkiyet sahibi olduğu, inanılanın ise sadece şekli hak sahibi olduğu düşüncesi yerinde değildir. Alman hukuku doktrininde savunulan ve yukarıda ifade edilen bu görüşler, Türk İsviçre hukuklarında kabul görmemiştir. Bundan ötürü inanılan esas sermaye payından doğan hak ve borçların tek sahibidir. Taraflar arasındaki inanç sözleşmesinde mali hakların inanana ait olacağı yönündeki anlaşma özünde müstakbel alacağın temlikine yönelik bir taahhüt olup ancak bu halde inanan şirketten muaccel olan kâr payı alacağının kendisine ödenmesini talep edebilir. Yönetsel haklar ise inanılana aittir. Şirketin idaresinden doğan bir zarar söz konusu olduğunda müdürlerin sorumluluğuna ilişkin davayı da ancak inanılan ortak sıfatıyla ikame edebilir. Türk-İsviçre ve Alman hukukları arasındaki bu farklılık özellikle inançlı işlem konusunun hacze konu olması yahut iflas masasına dâhil olması halinde bunun üzerinde istihkak iddiasına bulunulması ve iflas masasından çıkarılmasının talep edilmesi çerçevesinde değerlendirilmiştir. Çalışmanın devamında incelenecek olan Basel Eyalet Mahkemesinin kararı da bir açıdan bu esası ele almakta ve İsviçre hukukunda inançlı temlikin inanç konusu esas sermaye payının yalnızca şekli mülkiyetini naklettiği savına karşı çıkmaktadır.

Devreden inananın şirkette söz hakkı sahibi olmak için esas sermaye payını oysuz olarak devretmesi, yani oy hakkını elinde tutması mümkün değildir. Bunun yerine inanan ile inanılan arasındaki inanç sözleşmesi uyarınca oyda temsil hakkı tanınabilir yahut oy sözleşmesi yapılabilir. Oy sözleşmesi yapılması suretiyle talimata aykırı kullanılan oyun geçersiz olmayıp sadece tazminat yükümlülüğü doğurması karşısında inanana bir güvence sağlanmış olur ${ }^{82}$. Oy hakkının inanılan tarafından kullanılmasında önem arz eden bir diğer husus ise, oydan yoksunluk hallerinin inanan nezdinde doğmuş olmasıdır. Oydan yoksunluğa ilişkin düzenlemenin amacının menfaat çatışmalarını önlemek olduğu gerekçesiyle, oydan yoksunluk hallerinin inananın nezdinde doğmuş olmasının yeterli olacağı ileri sürülmektedir ${ }^{83}$. Lakin inanılan ortağın sadakat yükümü göz önüne alındığında ortak sıfatını haiz olmayan inananın nezdinde doğan hallerin inanılanın oydan yoksunluğuna yol açmayacağ kanaatindeyiz. Her ne kadar inanılanın, inanç sözleşmesi gereğince inananın menfaatini gözetmesi gerekse de şirkete karşı olan sadakat yükümlülüğü daha baskın olup bu ikisi arasında çatışma olması halinde her zaman şirketin menfaatini üstün tutmalıdır. Dolayısıyla inananın nezdinde doğan oydan yoksunluk hallerinde inanılanın şirketin menfaatleri doğrultusunda hareket etmesi gerekmekte olup bu yükümlülüğe aykırı hareketi TTK 613 hükmü çerçevesinde değerlendirilir.

\section{4. İnançlı Temlik Edilen Esas Sermaye Payının Hacze Konu Olması ve İnananın İflası}

Esas sermaye payı inançlı temlik işlemiyle birlikte artık yeni ortağın malvarlığında yer almaktadır. Bu nedenle inanılanın alacaklıları bu esas sermaye payı üzerinde haciz işlemi yaptırabilecekleri gibi, inanılanın iflas etmesi halinde esas sermaye payı iflas masasına dâhil olacaktır. Bu durumun inanana, yani eski ortağa zarar verdiği düşüncesiyle ve hakkaniyeti sağlamak amacıyla Alman hukukunda çeşitli teoriler ileri sürülmüş, bunlardan "şekli durum teorisi” ( formale Rechtsstelung) ve "şekli hak

82 Mühl, s. 149.

83 Mühl, s. 149. 
sahipliği teorisi” (Legitimationstheorie) Alman yargısında ve doktrininde benimsenmiştir. Bu teori uyarınca inanç konusu üzerindeki mülkiyet şekli / hukuki veya maddi / iktisadi olarak ayrılmakta ve gerçek hak sahibi olarak inanan görülmektedir. Buradan hareketle inanana esas sermaye payının iflas masasından çıkarılmasını talep hakkı (Aussonderungsrecht) tanınmaktadır ${ }^{84}$. Aynı şekilde inanç konusunun inanılanın alacaklılarından biri tarafından haczedilmesi halinde inananın bu kişilere karşı bir istihkak iddiasında bulunabileceği kabul edilmektedir ${ }^{85}$. Ancak Alman hukuk doktrininde ileri sürülen bu gerekçe Türk hukuku bakımından kabul edilemez. Daha önce belirtildiği üzere, inançlı temlik bir tam hak devridir. Bu nedenle kanaatimizce inananın yalnızca şekli hak sahibi olduğu gerekçesiyle iflas masasından çıkarmayı talep etme hakkı yoktur ${ }^{86}$. İnançlı temlik halinde inanana iflas masasından çıarma hakkı tanıyan İİK 188 hükmü hamiline ve emre yazılı senetlere özgü olup kıyas yolu ile tüm inançlı temlik hallerine uygulanamaz.

Türk hukuku bakımından yapmış olduğumuz bu tespit, inanılanın iflas etmesi halinde teminat altına alınan alacağı ifa etmiş olan inananın inanç konusunu, inanç sözleşmesi uyarınca adi iflas alacaklısı olarak masadan talep edemeyeceği sonucunu doğurmaktadır ${ }^{87}$. Ancak bu çıkarım, temelinde inanılana teminat sağlama amacı güden inançlı temlik ilişkisinde hakkaniyete aykırı bir duruma sebebiyet vermektedir. Bilhassa teminat altına alınan alacağın ifa edilmesine rağmen inanılanın inanç konusunun iflas masasınca paraya çevrilmesine katlanmak zorunda bırakılması, uygulamadaki ihtiyacın doğurduğu bu hukuki ilişkinin özüne aykırıdır. Kanaatimizce, doktrinde Antalya tarafından da savunulduğu üzere, teminat amacıyla inançlı temlik ilişkisinin gayesi göz önüne alınarak, inanana, inanılanın iflası halinde borcun ödenmiş olması koşuluyla inanç konusunun iflas masasından çıkarılmasını talep hakkının tanınması daha adil bir sonuç meydana getirecektir ${ }^{88}$.

84 Altmeppen / Roth, $\$ 15$, Rn. 46; Kraus, Münch. Hdb. GesR. III, \$26, Nr. 49; Konu hakkında ayrıntıll açıklamalar için bkz. Özsunay, İnançlı Muameleler, s. 194 vd. Teminat amaçlı inançlı temlikte inananın iflası halinde inanç konusu iktisadi olarak onun malvarlığında olduğu için, inanç konusu da iflas masasına dâhil olacağı, inanılanın bu halde iflas masasından çıkarma hakkının değil, (İ̈K 185 anlamında) bir rüçhan hakkı olduğu yönünde bkz. Reichert / Weller, MüKoGmbHG, \$ 15, Rn. 236; Kraus, Münch. Hdb. GesR. III, § 26 Nr. 50.

85 Reichert / Weller, MüKoGmbHG, \$15, Rn. 238; Kraus, Münch. Hdb. GesR. III, \$26, Nr. 51.

86 Özsunay, İnançlı Muameleler, s. 173; Eren, Borçlar Hukuku Genel Hükümler, s. 386; Tuncer-Kazancı, İ., İnançlı İşlemde İşlemin Taraflarının İflası ve İflasın İnançlı İşleme Etkisi, Prof. Dr. Hakan Pekcanıtez’e Armağan, DEÜHFD, C. 18, Özel Sayı 2014, (s. 2811 - 2834) s. 2825. Oğuz, A., s. 254. İsviçre Hukukunda aynı yönde bkz. Merz, s. 457; Müller, Art. 18, Nr. 414; Jäggi / Gauch / Hartmann, Art. 18, N. 214; Guhl / Koller / Schnyder / Druey, \$15, N. 30.

87 Tuncer-Kazancı, s. 2825. Saf inançlı işlemlerde ise vekâlete ilişkin hükümlerin kıyasen uygulanması kabul edilmektedir. $\mathrm{Bu}$ nedenle esas sermaye payının saf inançlı işleme konu olduğu hallerde inananın TBK 509/I'de öngörülen kanuni temlikten yararlanması hem Türk hem de İsviçre hukukunda (OR Art. 401/I) kabul edilmektedir. Bkz. Kocayusufpaşaoğlu / Hatemi / Serozan / Arpact, \$35, Nr. 47 vd.; Tuncer-Kazanc1, s. 2829; Merz, s. 458; Jäggi / Gauch / Hartmann, Art. 18, N. 215; Guhl / Koller / Schnyder / Druey, \$15, N. 30. Aksi yönde bkz. Özsunay, İnançlı Muameleler, s. 207-208. Bu hükmün hem saf hem karma inançlı işlemlerde uygulanabileceği yönünde ise bkz. Altaş / Kurt, s. 20. Kanaatimizce TBK 509/I hükmü sadece vekâlete ilişkin hükümlerin kıyasen uygulandığı saf inançlı işlemlerde uygulama alanı bulabilir. $\mathrm{Bu}$ nedenle teminat amacıyla inançlı temlikte bahsedilen hükme dayanılarak inananın korunması söz konusu olamaz. Nitekim teminat amaçlı inançlı temlikte inanç sözleşmesinin temelinde inanılanın menfaatini gözetme amacını içeren bir vekâlet ilişkisi değil, inanana teminat sağlamayı amaçlayan bir rehin ilişkisi yer almaktadır.

88 İnanç sözleşmesinin gereği yerine getirildikten sonra inanılanın iflas etmesi halinde, inananın inanç konusu şeyin iflas masasından çıkarılmasını talep edebileceği yönünde bkz. Antalya, Borçlar Hukuku Genel Hükümler C. V / 1,1, $\$ 15$ N. 1548. 
Bu kabul ile Alman hukukunda hakkaniyeti sağlama çabasının bir ürünü olan mülkiyetin şekli ekonomik ayrımına gidilmesi gerekliliği de ortadan kalkacaktır.

İnananın iflas etmesi halinde ise, İ̇K 195 uyarınca tüm borçları muaccel olur. Buna inançlı temlik ile temin edilen borcu da dâhildir. İnananın alacaklıları inançlı temlikten doğan iade borcuna el atabilir $^{89}$. Bu durumda iflas masası inanç konusunu paraya çevirebilir ${ }^{90}$, artan kısmı masaya iade etmekle yükümlüdür; eksik kalan kısım için adi iflas alacaklısı olarak masaya başvurur. İflas anında borcun ödenmiş olması veya iflas açıldıktan sonra iflas masası tarafından borcun ödenmesi halinde esas sermaye payının iadesini talep hakkı iflas masasına aittir ${ }^{91}$.

\section{Taraflar Arasındaki İnanç ilişkisinin Sona Ermesi}

Taraflar arasındaki inançlı işlem, sürenin sona ermesi, belirlenen şartın gerçekleşmesi, borcun ifa edilmesi gibi sebeplerle sona erebilir. Borcun tam olarak ifası ile sona erme halinde inanılan esas sermaye payını inanana iade etmekle yükümlüdür ${ }^{92}$. İnananın iadeye ilişkin talep hakkı aynî değil şahsî bir hak olduğu için istihkak davası açması söz konusu değildir ${ }^{93}$. Nitekim inanç konusu üzerinde hak sahipliği inanılandadır. Burada inanan ancak TBK 112 uyarınca aynen ifa davasıyla iadenin gerçekleştirilmesini ${ }^{94}$ yahut aralarındaki inanç sözleşmesinin gereği gibi ifa edilmediği gerekçesiyle zararının giderilmesini talep edebilecektir ${ }^{95}$. Yukarıda da belirtildiği üzere inançlı temlik amacıyla esas sermaye payının devrinde genel kurul tarafından bu amaç bilinerek onay verilse dahi iade işlemi esnasinda tekrar genel kurul onayı alınması zorunludur.

Teminat altına alınan borcun ödenmemesi halinde ortağın nasıl hareket edeceği inanç sözleşmesiyle kararlaştırılabilir ${ }^{96}$. Ortak (inanılan), esas sermaye payını paraya çevirip alacağını oradan

89 Tuncer-Kazancl, s. 2821.

90 Tuncer-Kazancı, s. 2823. Paraya çevirme işleminin inanılan tarafından gerçekleştirileceği yönünde bkz. Özsunay, İnançlı Muameleler, s. 212.

91 Reichert/Weller, MüKoGmbHG, \$15, Rn. 237.

92 Poroy/ Tekinalp/ Çamoğlu, Ortaklıklar I, Nr. 772f; Arslanlı/ Domaniç, s. 271. Alman hukukunda kabul gören inançlı işlemin bozucu şarta bağlı bir işlem olduğu, bu nedenle borcun ödenmesiyle inançlı işlem konusunun mülkiyetinin inanana kendiliğinden döneceği görüşü hukukumuz bakımından kabul edilemez. Zira Tandoğan’ın da belirttiği üzere, taşınmazlarda şarta bağlı tescil yapılamayacağı gibi, taşınırlarda da bozucu şart gerçekleşse bile (geriye) devir şarttır. Bkz. Tandoğan, İnançlı İşlem, s. 80. Aynı sonuca inançlı işlemin, rehinden farklı olarak fer'î bir hak doğurmadığından da ulaşılabilir; bkz. Altaş / Kurt, s. 8. İnanç sözleşmesinden doğan taleplerin ileri sürülmesi için on yıllık zamanaşımı süresinin uygulanacağı yönünde bkz. Kılıçoğlu, s. 249.

93 Antalya, Borçlar Hukuku Genel Hükümler C. V/ 1,1, §15 N 1547.

94 Buna ilişkin bir kararında Yargıtay aynen şu ifadelere yer vermiştir: "İnançlı işlem, kazandırmayı yapan kişiye yani inanana belirli şartlar gerçekleşince, kazandırmanın iadesini isteme hakkı sağlayan bir sözleşmedir. Bu yükümlülüğün yerine getirilmemesi halinde bunun dava yoluyla hükmen yerine getirilmesi istenebilir.” Yarg. 14. HD, 26.11.2018, E. 8996/ 2016, K. 8242/ 2018; karar için bkz. http://www.karararama.yargitay.gov.tr (erişim tarihi: 03.12.2019).

95 Arslanlı, Limited Şirketler II, s. 192; Arslanlı / Domaniç, s. 271; Özsunay, İnançlı Muameleler, s. 151, s. 190-191; Antalya, Borçlar Hukuku Genel Hükümler C. V/ 1,1, \$15 N 1546; Altaş / Kurt, s. 18.

96 “...davacının \%25 payını teminat amaçlı olarak devrettiği anlaşılmaktadır. Anılan protokolde teminat amaçlı olarak devir edilen bu payların hangi koşullarda davacıya iadesi belirtilmiş, bir hesaplama tarzı kararlaştırılmıştır.... Mahkemece bozmaya uyulmasına rağmen gereğinin yapılmaması, davacıya iade edilecek payın miktarının protokolün 6. Maddesine ve bozma ilamındaki açıklamaya göre tespit edilmesi gerekirken...” Yarg. 11. HD, 09.12.2014, E. 4201/ 2014, K. $19353 / 2014$. 
karşılayabilir. Bu satış esnasında TMK 2 hükmüne uygun hareket edilmeli ve inananın menfaati de gözetilmelidir. Bu yükümlülük açıkça inanç sözleşmesinde düzenlenmemiş olsa bile hem rehin hukukuna ilişkin kuralların kıyasen uygulanmasından hem de TMK 2'den ${ }^{97}$ doğar. Ancak ortak (inanılan), inanç konusunu paraya çevirmek zorunda değildir, zira lex commissoria yasağı inançlı temlik halinde söz konusu olmaz ${ }^{98}$.

$\mathrm{Bu}$ nedenle taraflar inanç sözleşmesiyle borcun ödenmemesi halinde ortak sıfatının inanılanda kalacağı hususunu kararlaştırabilir.

\section{BASEL EYALET MAHKEMESI'NIN 3 ŞUBAT 2019 TARIHLI ZB.2018.35 SAYILI KARARININ ÖZETI}

\section{A. OLAYIN ÖZETi}

Davacı C ile davalı A arasında 14.9.2013 tarihinde akdedilen “Tohum Alımına İlişkin Yatırım Anlaşması"na aykırılık hasebiyle ilk derece mahkemesinde görülen uyuşmazlıkta mahkeme, A’yı bir miktar tazminat ödemeye mahkûm etmiştir. Bu karara karşı eyalet (istinaf) mahkemesine itiraz eden A, babası L’nin C'den olan alacağını kendisine temlik ettiği ve bu iki alacak kalemi arasında takas yapılması gerektiği iddiasında bulunmuştur. Eyalet (istinaf) mahkemesinin kararı L'nin C'den gerçekten bir alacağı olup olmadığına ilişkin olup, bu çerçevede mahkemece L ve C arasında var olduğu iddia edilen inanç sözleşmesi değerlendirilmiştir.

\section{B. L VE C ARASINDAKI HUKUKI ILIŞKI}

2005 yılında L, C ve C’nin iş ortağı I “üzerinden” E GmbH, F GmbH, G GmbH ve H GmbH olmak üzere dört adet limited şirket kurmuştur. Taraflar arasında akdedilen inanç sözleşmesi uyarınca $\mathrm{E}$ GmbH’nın yöneticisi C; F GmbH’nın yöneticisi C ve I; G GmbH’nın yöneticisi C ve I; H GmbH’nın

Karar için bkz. www.kararara.com (erişim tarihi: 11.11.2020)

97 Özsunay, İnançlı Muameleler, s. 151.

98 Cansel, Menkul Rehni, s. 189 - 190; Köprülü, B./ Kaneti, S., Sınırlı Aynî Haklar, Genişletilmiş ve Yenilenmiş 2. Bası, İstanbul 1982-1983, s. 462; Nomer, H., Teminat Amaçlı Vefalı Satışlar ile İnanç Sözleşmeleri ve Lex Commissoria Yasă̆1, Prof. Dr. Cevdet Yavuz’a Armağan, MÜHFD, C. 22, S. 3, s. 2014; Esener, Muvazaalı Muameleler, s. 160-161; Özsunay, İnançlı Muameleler, s. 139-140; Kuntalp, E., Lex Commissoria Yasağı Kavramı, Koşulları ve Uygulama Alanı, İnan Kıraç’a Armağan, Galatasaray Üniversitesi Yayını, İstanbul 1994, (s. 151 - 162) s. 159 - 160. Kuntalp’in de belirttiği üzere, bu halde teminat konusunun değerinin teminat altına alınan alacağı aşması halinde aşan kısım teminat konusunu açık artırma veya serbestçe satıp satış bedelinden alacağını alabileceği görüşündedir. Bu yönde kararlar için bkz. Yarg. 14 HD, 14.3.2019, E. 16087/ 2016, K. 2373/ 2019; Yarg. 1 HD, 19.06.2019, E. 8019/2016, K. 3930/ 2019; bahsedilen kararlar için bkz. http://www.karararama.yargitay.gov.tr (erişim tarihi: 03.12.2019). İsviçre Federal Mahkemesi de aynı görüştedir. Bkz. BGE 56 II 444. Bkz. Arslanl, H., Türk Ticaret Kanunu Şerhi, İkinci Kitap - Yedinci Fasıl, Limited Şirketler (Madde 503-556), İkinci Kısım (Limited Şirketler (m.518-535)), Fakülteler Matbaası, İstanbul 1963, s. 192; Aydıncık, s. 138, özellikle dn. 35; Helvacı, İ., Türk Medeni Kanunu’na Göre Lex Commisoria Yasağ1, Doktora Tezi, İstanbul 1997, s. 113; Mühl, s. 154; Tuncer-Kazancı, s. 2824; Makaracı - Başak, s. 286; Parlak-Börü, s. 263; Dereli, Z., Lex Commissoria Yasağı, Ankara Üniversitesi Sosyal Bilimler Enstitüsü Yayınlanmamış Yüksek Lisans Tezi, Ankara 2009, s. 72 vd.; OktayÖzdemir, S., “Teminat Amaçlı Alacak Devri ve Toptan Temlik Sözleşmeleri”, İÜHFM, C. LVII, S. 1-2, Y. 1999 , s. 280. 
yöneticisi I'dır ${ }^{99}$. Ayrıca inanç sözleşmesinin 6. maddesinde C'ye hizmetleri karşılığı her ayın başında vergi ve masraflar hariç $523 €$ ödenmesi kararlaştırılmıştır.

Şirketlerin yönetim yapılarına ilişkin olarak belirtilmesi gereken bir diğer husus ise A’nın annesi ve L’nin eşi olan J'nin F GmbH; A’nın kardeşi ve L'nin oğlu olan K’nın G GmbH’nın yöneticilerinden olduğudur.

\section{TARAFLARIN L VE C ARASINDAKI HUKUKI ILIŞKIYE DAIR IDDIA VE SAVUNMALARI}

\section{A'nın Iddiaları}

Babası L'nin C'den olan alacağını devralan A; L ile C’nin arasındaki hukuki ilişkiye dair birtakım iddialarda bulunmuştur. Bunların ilki, L ile C arasında mevcut olan ve limited şirket esas sermaye payının devrini konu aldığı iddia edilen inanç sözleşmesinin esas sermaye payı üzerindeki mülkiyet hakkına yaptığı etkiye ilişkindir. Bir diğer iddiası ise, daha sonradan C’nin ödemezlik def’i olarak ileri sürdüğü ücretin çoğunlukla hiç ödenmemesine ilişkin olarak, C’nin ücret hakkından feragat ettiğine ilişkindir.

\section{a. Limited Şirket Esas Sermaye Payını Konu Alan Inanç Sözleşmesinin Mülkiyet Hakkına Etkisi Yönündeki Iddia}

A’nın iddiası, L’nin kendisine devrettiği alacağın kaynağını ortaya koymaya yöneliktir. Nitekim L, C'den olan alacağının aralarındaki inanç sözleşmesinden doğduğunu ifade etmiştir. Buna göre L, limited şirketlerdeki esas sermaye payının gerçek sahibidir ve C’nin bu şirketlerin gelirinin azalmasına sebep olmasından ötürü zarara uğradığını ileri sürmektedir.

A bu iddiasını temellendirmek için inançlı sözleşmenin türlerine göre bir ayrım yapılması gerektiğini ifade etmiştir. Buna göre inançlı temlik, meşru hamil görüntüsü sağlayan devir (Legitimationsübertragung) ve inançlı mülkiyet devri (fiduziarische Eigentumsübertragung) olarak ikiye ayrılmaktadır. İnançlı mülkiyet devri halinde inanılan, belirli bir süre için ortaklıktan doğan tüm hak ve yükümlülüklerin sahibi olur, yani tam yetkilidir. Bu güçlü konum sözleşmenin taraflarının bu yönde açık iradelerinin olmasıyla sağlanır. Buna karşın meşru hamil görüntüsü sağlayan devir, esas sermaye payının mülkiyetinin geçmesi sonucunu doğurmaz. Bu devir, devralanı yalnızca dışarıdan hak sahibi kılmaya yöneliktir. Bu durumda devralanın iç ilişkideki durumu ile dış ilişkideki durumu birbirinden farklılık göstermektedir.

A, bu beyanlarının ardından L ve C arasındaki inanç sözleşmesinde L'nin esas sermaye paylarının \%100 sahibi olduğunun beyan edildiğini ve sözleşmenin lafzının inançlı mülkiyet devri neticesini imkânsız kıldığını ifade etmiştir. Dolayısıyla A, L’nin başından beri şirketin kurucu ortağı olduğunu, dış ilişkide C’nin ortak olarak göründüğünü, ancak iç ilişkide L'nin ortak olduğunu iddia etmiştir.

99 A, H GmbH’nın yöneticileri arasında C’nin de bulunduğunu iddia etmişse de bunu ispatlayamamış; bu husus ayrıca mahkemece önemli görülmemiştir. p. 3.2. 


\section{b. C'nin Sözleşmeden Doğan Ücret Alacağından Feragat Ettiği Yönündeki İddia}

A, C’nin sözleşmeden doğan bir ücret alacağı olmasına rağmen C’nin bu hakkından feragat ettiğini ileri sürmüştür. A’nın iddiasına göre C, şirketler aracılığıyla işletilmekte olan biyogaz işletmesinin kâr elde etmesi için tam kapasite çalışması gerektiğini bildiğini, bundan ötürü şirketler kâr elde etmeye başlayana kadar ücret alacağından vazgeçip onun yerine kâr elde edildikten sonra bu kârdan pay almayı kabul ettiğini ve bu anlaşmaların sözlü gerçekleştirildiğini ileri sürmüştür. Ayrıca J ve $\mathrm{K}$ de şirketten olan huzur hakkı alacaklarından şirketler kâr edinceye kadar vazgeçmişlerdir. A, bu iddialarına tanık olarak babası L, annesi J ve kardeşi K’yi göstermiştir. Buna ek olarak feragat iddiasına bir sebep daha olarak A, L aleyhine yürütülen iflas işlemlerinden haberdar olup, bu nedenle alacağından vazgeçtiğini de ileri sürmüştür. Bu iddia çerçevesinde A en son olarak C’nin ücret alacağına binaen hiçbir zaman fatura göndermediğini de ifade etmiştir.

\section{C'nin Savunmaları}

Kararda A’nın 1. başlıkta aktarılan iddialarına karşılık C’nin savunmasına yer verilmemiştir. C’nin savunmaları ziyadesiyle 2. başlık çerçevesinde şekillenmiştir. Bu kapsamda C, inanç sözleşmesinden doğan ücret alacağından feragat ettiğine ve kârdan pay alacağına yönelik bir sözlü anlaşma gerçekleştirildiğine dair iddiaya itiraz etmiştir. C, şirketi yönetmek üzere anlaştıklarını; biyogaz piyasası ve işletmenin işleyişine dair daha önceden bir bilgisi olmadığını; J ve K’nin aynı ailenin birer üyesi olmalarından ötürü şirketten şu an alacaklarını tahsil etmemede büyük çıkarları olduğunu, ancak kendisinin aile üyesi olmadığını ve şirkete sunmuş olduğu hizmetin karşılığını talep ettiğini ifade etmiştir. Bunu yanı sıra C, L’nin iflas yoluyla takip edildiğini şirketin kurulmasından çok sonra öğrendiğini, ancak bunu başından itibaren biliyor olsa dahi bu durumun ücret alacağından vazgeçtiği anlamına gelmeyeceğini ileri sürüyor. Bu savunmalar kapsamında dosyaya sunulan ve C tarafından Lye gönderilen bir e-postanın içeriği ise şu şekildedir: "Şirketin iyi işletilmesine rağmen likidite sıkıntısı olmasını her zaman anlayışla karşıladım ve bu nedenle hep çok sabırlıdım. Ancak giderek anlamakta zorlandığım husus faturaların ödenmesinde her zaman en son sirada yer almam ve diğer herkesin benden önce gelmesi. 2.300 İsviçre Frangı tutarındaki muhasebe işleri ve huzur hakkı ödemesi gerçekten bir sorun olmazdı ve bunlar her zaman ödenseydi şu an bu sorun yaşanmazdı".

\section{EYALET (ISTINAF) MAHKEMESININ DEĞERLENDIRMESi}

\section{L ve C Arasındaki Inanç Sözleşmesi'nin Esas Sermaye Payı Üzerindeki Mülkiyet Hakkına ilişskin Değerlendirmeleri}

Eyalet (İstinaf) Mahkemesi ilk olarak L’nin şirkette hiçbir zaman ortak sıfatını haiz olmadığını tespit etmiştir. Bundan ötürü A’nın iddiasının aksine, L’nin esas sermaye paylarını meşru hamil görüntüsü oluşturmak amacıyla C’ye devretmiş olmasının mümkün olmadığı sonucuna varmıştır.

Bu tespitin ardından Eyalet (İstinaf) Mahkemesi bu çalışmanın sebebini teşkil eden bir konuya değinmiş ve taraflar arasındaki inanç sözleşmesinin esas sermaye payı üzerindeki mülkiyet hakkını 
nasıl etkilediğini değerlendirmiştir. Bu çerçevede Eyalet (İstinaf) Mahkemesince ilk tespit edilen husus, inanç sözleşmesine uygulanması gereken hukukun İsviçre hukuku olduğudur. Bu tespit birazdan yer verilecek değerlendirmelerin, çalışmamızın devamında ele alınacak olan Alman hukukundan ayrıldığını belirlememiz için önem arz etmektedir.

İnanç sözleşmesine İsviçre hukukunun uygulanacağını tespit eden Eyalet (İstinaf) Mahkemesi ardından inanç ilişkisinin inanılanın inanç konusunu tam yetkili olarak iktisap ettiğini, ancak inanç konusu üzerindeki hakkını inanç sözleşmesine uygun olarak kullanması ve/veya devretmesi gerektiğini ifade etmiştir. İnanç ilişkisinin ayırt edici özelliklerinden biri, inanılanın iktidar alanının yetkilerinden daha geniş olmasıdır. Bu sözleşme ile öngörülen tasarruf yetkisi kısıtlamaları yalnızca nispî etkiyi haiz olup taraflar arasında sonuç doğurmaktadır. Eyalet (İstinaf) Mahkemesi İsviçre hukukunda inanç ilişkisinin temelinde "tam hak teorisi”nin (Vollrechtstheorie) yattığını vurgulamıştır. Alacak hakkı ve esas sermaye payı gibi diğer haklar üzerinde gerçekleştirilecek olan inanç işlemlerinde geçerli olan tam hak teorisi nedeniyle, mülkiyetin iç ve diş ilişkide ayrılması yahut ekonomik mülkiyet/hukuki mülkiyet veya şekli mülkiyet/gerçek mülkiyet gibi ayrımlara yer yoktur. Şirketin kurucusu olan inanılan hem şirkete hem de üçüncü kişilere karşı ortak ve esas sermaye payının sahibidir. Alman hukukunda kabul edilen yetkilendirme amacıyla inançlı işlem (Ermächtigungstreuhand) kural olarak İsviçre hukukunda geçerli değildir. Bu nedenle A’nın inançlı sözleşme dolayısıyla L'nin esas sermaye payının gerçek sahibi olduğu yönündeki iddiası İsviçre hukuku bakımından kabul edilebilir değildir. Buna ek olarak ortaklıklar hukukunda hamile yazılı pay senetleri açısından mümkün olabilecek meşru hamil görüntüsü yaratmak amaciyla pay sahipliği sıfatı devredilmeksizin senet zilyetliğinin devri mümkünken, bu uygulamanın nama yazılı senetler açısından doktrinde de hâkim olan güncel görüş tarafından reddedildiği ifade edilmiştir. Bu nedenle limited şirket esas sermaye payının yalnızca meşru hamil görüntüsü yaratmak amacıyla devredilmesi mümkün değildir.

Eyalet Mahkemesi bu değerlendirmeleri sonucunda ilk derece mahkemesiyle aynı yönde, L'nin hiçbir zaman ortak sıfatını haiz olmadığı, dolayısıyla şirketin gelirlerindeki azalmadan ötürü bir zarara uğramasının söz konusu olmadığı neticesine ulaşmıştır.

\section{C'nin Sözleşmeden Doğan Ücret Alacağından Feragat Ettiği İddiasına İlişkin Değerlendirmeleri}

Eyalet (İstinaf) Mahkemesi, C’nin inanç sözleşmesinden doğan bir alacağın varlığı kabul edilse dahi bunun kendisine ileri sürülemeyeceği, zira ücret alacağının kendisine ödenmediği yönündeki savunmasını haklı görmüştür. Yazılı olarak gerçekleştirilen hiçbir inanç sözleşmesinde ücret alacağından feragate ve/veya kârdan pay almaya yönelik bir düzenlemeye yer verilmediği, bu durumun sebebinin ise A tarafından ortaya konulamadı̆̆ı, bu nedenle feragate ilişkin iddianın inandırıcı olmadığı ifade edilmiştir.

A’nın biyogaz işletmesinin giderlerinin ilk yıllarda gelirlerini aştığının taraflarca bilindiğine ilişkin iddiasına ilişkin tek delilinin L'nin tanıklığı olduğu, ilk derece mahkemesinin bu hususta A’nın ispat yükümlülüğünü yerine getirmediği çıkarımının yerinde olmadığı belirtilmiştir. Eyalet 
(İstinaf) Mahkemesi bunu, A’nın bir avukat tarafından temsil edilmiyor olmasına rağmen ilk derece mahkemesinin iddianın neden kabul edilmediğine ilişkin olarak yalnızca halin şartlarını gösterip daha fazla gerekçe sunulmaması şeklinde gerekçelendirmiştir. Bununla birlikte, bu tespitin sonuç açısından önemli olmadığı da ifade edilmiştir.

L aleyhine yürütülen iflas takibinin, ücret alacağından feragat edilmesi sonucunu doğurmayacağı, en fazla (e-postadan da anlaşıldığ 1 üzere) ödemede bir gecikmeye neden olabileceği vurgulandıktan sonra, A’nın beyanları arasında L aleyhine yürütülen iflas işlemlerinin feragat anı itibariyle sona erdiği şeklinde bir ifadeye verildiği ve A’nın beyanları arasında çelişki olduğu da belirtilmiştir.

Eyalet Mahkemesi, C’nin iddia edilen feragatine ilişkin olarak A tarafından tanık gösterilen L, J ve K arasındaki sıkı ailevi, ticari ve menfaat bağı hasebiyle L, J ve K’nin beyanları ile A’nın beyanı arasında ispat gücü bakımından bir farklılık olmadığı; 4.5.2016 tarihinde şirket yöneticisi olarak alınan M’nin ise işe alınma tarihi itibariyle sözlü feragate tanık olamayacağı nedeniyle feragat iddiasının ispatlanamadığı sonucuna varmıştır.

\section{SONUÇ}

Eyalet (İstinaf) Mahkemesi sonuç itibariyle L'nin hiçbir zaman ortak sıfatını kazanmadığını; esas sermaye payının mülkiyetinin ona ait olmadığını ve dolayısıyla uğradığı bir zarardan bahsedilemeyeceğini; A’nın L'den devraldığı alacak geçerli olmadığı ve bozmayı da gerektiren başkaca bir sebep bulunamadığı için itiraz reddedilmiştir.

\section{BASEL EYALET MAHKEMESI KARARININ DEĞERLENDIRILMESi}

Yukarıda özetine yer verilen Basel Eyalet (İstinaf) Mahkemesinin kararında, esas sermaye payının inançlı temlike konu olması açısından iki esas ele alınmıştır. Bunlar;

- Bir ticari işletme işletmek amacıyla limited şirket kurulmasına ilişkin inanç sözleşmesi esas sermaye payının inançlı temliki anlamına gelir mi?

- Esas sermaye payının inançlı temlike konu olması halinde inanan, şirketin kurucu ortağı ve yöneticilerinden biri olan inanılanın şirkete zarar verdiği gerekçesiyle inanç sözleşmesinin ihlal edildiğini ileri sürebilir mi?

Ticari işletme işletmek amacıyla limited şirket kurulmasına ilişkin inanç sözleşmesinin esas sermaye payının inançlı temliki anlamına gelip gelmediğinin değerlendirilebilmesi için ilgili inanç sözleşmesinin konusu ve taraflarına bakılması gerekir. Esas sermaye payının inançlı temlikine yönelik inanç sözleşmesi, hem bu çalışmanın başında inançlı temlike ilişkin genel açıklamalarda hem de Basel Eyalet Mahkemesi’nin kararında ifade edildiği üzere, ortak ile devredilen arasında akdedilmektedir. Noter tarafından onaylanan bu sözleşmenin ardından devrin hüküm ve sonuçlarını doğurabilmesi için şirket sözleşmesinde aksi yönde bir düzenlemeye yer verilmedikçe genel kurulun 
onayı alınır. Devre ilişkin sözleşmenin taraflarından birinin ortak sıfatını haiz olması zorunluluğu ve devir için genel kurul onayının aranması, esas sermaye payının inançlı temlike konu olması halinde devredenin mevcut bir şirkette ortak olmasını zorunlu kılmaktadır ${ }^{100}$. Ayrıca olayda akdedilen inanç sözleşmesi, aleyhinde iflas takibi yapılan bir kişinin şirket kurmaktan kaçınması nedeniyle bu işlemin bir başkası üzerinden gerçekleştirilmesine yöneliktir. Buna karşın karara konu olayda dört adet limited şirketin kurulması ve yönetilmesine dair bir inançlı işlem gerçekleştirilmiş olup, bir mal veya hakkın devri söz konusu değildir ${ }^{101}$. Dolayısıyla mahkemenin, L’nin ne kuruluşta aslen ne de sonradan devren ortak sıfatını haiz olduğu, bu nedenle esas sermaye payının inançlı temlik edilmesinin mümkün olmadığı yönündeki değerlendirmesi yerindedir.

Esas sermaye payının inançlı temlike konu olması halinde inananın, şirketin kurucu ortağı ve yöneticilerinden biri olan inanılanın şirkete zarar verdiği gerekçesiyle inanç sözleşmesinin ihlal edildiğini ileri sürmesine ilişkin olarak yapılacak değerlendirmede ise, bir inançlı temlikin mevcut olduğu varsayımından hareket edilmelidir. Bir diğer ifadeyle, olayda esas sermaye payının inançlı temliki söz konusu olsaydı dahi inananın, şirketin uğramış olduğu zarardan ötürü tazminat hakkı olup olmadığı incelenmelidir. Olayda L, bu şirketin gerçek ortağının kendisinin olduğunu ve şirkete zarar verilmesinin inanç sözleşmesinin ihlali anlamına geldiğini iddia etmektedir. İnançlı temlike ilişkin açıklamalarımızda da yer verdiğimiz üzere, inançlı temlikte inanılan inananın menfaatlerini de gözetmekle yükümlü olup, inanç konusunu sözleşmeye uygun kullanmakla mükelleftir. İnançlı temlikin ardından şirketin gelirlerinin azalması tek başına inanılanın inanç sözleşmesine aykırı hareket ettiği anlamına gelmeyecek olup, yönetici sıfatını haiz olan inanılanın tedbirli bir yönetici olarak karar verip vermediği incelenmeli, şirket genel kurulunda alınan kararlarda ise, inanılanın etki oranı (örneğin hâkim pay sahibi olup olmadığı) değerlendirilmelidir. Tüm bu değerlendirmelerden sonra inanılanın bu zararın oluşmasında kusuru olduğu tespit edilebiliyorsa, bu halde inanan, inanç sözleşmesine aykırı hareket edildiği iddiasını başarıyla ileri sürebilir. Bu çerçevede dikkat edilmesi gereken husus, inananın, inanılana müdürün sorumluluğu kapsamında dava açamayacağıdır; zira daha önce ifade edildiği üzere inanan, sorumluluk davası açılması için aranan pay sahibi sıfatını (TTK 553/I ve 555) haiz değildir. Benzer şekilde yöneticinin şirkete vermiş olduğu zararın inançlı temlik yapısı ile şirket yerine ortağa ödenmesi de söz konusu olmaz. Bu halde inanan, inanç sözleşmesine aykırılıktan ötürü kendisinin uğramış olduğu zararın yine kendisine ödenmesini talep edebilir.

100 Belirtmeliyiz ki inananın bir şirket kurup paylarını bir müddet elinde tuttuktan sonra inanılana devretmesi amacını güden bir inançlı temlik de yapılabilir. Bu durumda saf inançlı işlemden söz edilecek olup, çalışmamızın başında kısaca yer verdiğimiz ve Alman hukuk doktrininde inançlı işlemlerin tasnifinde başvurulan "Erwerbstreuhand" yahut "Vereinbarungstreuhand" söz konusu olur.

101 İnanılanın inanç konusunu inanandan değil de başka bir kişiden edindiği durum için nam-1 müstear terimi kullanılmaktadır. Bu halde inançlı işlemin söz konusu olup olmadığı hususunda doktrinde farklı görüşler ileri sürülmüş olup, bu çalışmanın kapsamını aşacağı için sadece tartışmaya işaret etmekle yetiniyoruz. Doktrin ve Yargıtay’ın bu konudaki görüşleri ve ayrıntılı değerlendirmeler için bkz. Kocayusufpaşaoğlu/ Hatemi/ Serozan/ Arpacı, § 35, Nr. 60 vd. 


\section{KAYNAKÇA}

Aebi-Müller, Regina E. (Hrsg.) / Müller, Christoph (Hrsg.), BK - Berner Kommentar: Obligationenrecht, Allgemeine Bestimmungen: Art. 1-18 OR mit allgemeiner Einleitung in das Schweizerische Obligationenrecht, Stämpfli Verlag AG, 2018.

Akın, Murat Yusuf, Anonim Ortaklıkta Bağlı Nama Yazılı Hisseler, Vedat Kitapçılık, İstanbul 2014.

Altaş, Hüseyin/ Kurt, Leyla Müjde, “İnançlı İşlemler”, İnönü Üniversitesi Hukuk Fakültesi Dergisi, C. II, S.II, Y. 2011, s. 1-28.

Altmeppen, Halger/ Roth, Günther H., Gesetz betreffend die Gesellschaften mit beschränkter Haftung, 9. Auflage, C.H. Beck, 2019.

Antalya, Gökhan, Borçlar Hukuku Genel Hükümler C. V/ 1,1, 2. Bası, Seçkin Yayıncılık, Ankara 2019. (C. V/1, 1)

Armbrïster, Christian, Die treuhänderische Beteiligung an Gesellschaften, Carl Heymanns Verlag, 2001.

Armbrüster, Christian, “Treuhänderische GmbH-Beteiligungen (I) Begründung, Übertragung, Umwandlung, Beendigung", GmbHR 2001, s. 941-950. (Anılış: Treuhänderische GmbH-Beteiligungen (I))

Armbrüster, Christian, "Zur Beurkundungsbedürftigkeit von Treuhandabreden über GmbH-Anteile Zugleich ein Beitrag zu den Formzwecken des $\$ 15$ Abs. 4 Satz 1 GmbHG-”, DNotZ1997, (s.762-786). (Anılış: Beurkundungsbedürftigkeit von Treuhandabreden über GmbH-Anteile)

Arslanlı, Halil, Türk Ticaret Kanunu Şerhi, İkinci Kitap - Yedinci Fasıl, Limited Şirketler (Madde 503-556), İkinci Kısım (Limited Şirketler (m.518-535)), Fakülteler Matbaası, İstanbul 1963.

Arslanlı, Halil/ Domaniç, Hayri, Türk Ticaret Kanunu Şerhi, C. III, Limited Şirketler Hukuku Ve Uygulaması, Hisseli Komandit Şirketler, İstanbul 1989.

Aydıncık, Şirin, "Bir İnançlı İşlem Olarak Alacağın Teminat Amacıyla Temliki”, İÜHFM, C. LXIVS.1, 2006, s. 131-194.

Bahtiyar, Mehmet, Ortaklıklar Hukuku, Güncellenmiş 14. Bası, Beta Basım Yayın, İstanbul 2020.

Baumbach, Adolf/ Hueck, Alfred/ Servatius, Wolfgang, Gesetz betreffend die Gesellschaften mit beschränkter Haftung, 21. Auflage, C. H. Beck, 2017.

Bork, Reinhard (Hrsg.) / Schäfer, Carsten (Hrsg.), GmbHG - Kommentar zum GmbH-Gesetz, 3. Auflage, Köln 2015. İçinde: Brandes, Stephan.

Bormann, Michael (Hrsg.) / Kauka, Ralf (Hrsg.) / Ockelman, Jan (Hrsg.), Handbuch GmbH-Recht, 3. Auflage, Zap Verlag, 2015. İçinde: Schulze Steinen, Mathias.

Bügler, Reto, Der GmbH-Anteil Insbesondere dessen Erwerb, Übertragung und Verlust (de lege lata et ferenda), Zürich, 2004.

Bühren, Simon/ von der Crone, Hans Caspar, "Positive Beschlussfeststellungsklage”, SZW 86 (2014), s. 564572.

Dereli, Zeliha, Lex Commissoria Yasağı, Ankara Üniversitesi Sosyal Bilimler Enstitüsü Yayınlanmamış Yüksek Lisans Tezi, Ankara 2009.

Eckhart, Dirk (Hrsg.) / Hermanns, Marc (Hrsg.), Kölner Handbuch Gesellschaftsrecht, Carl Heymanns Verlag, 2017. (KölnerHdbGesR)

Eren, Fikret, Borçlar Hukuku Genel Hükümler, 23. Bası, Yetkin Yayınları, Ankara 2018. (Anılış: Borçlar Hukuku Genel Hükümler)

Eren, Fikret, Mülkiyet Hukuku, 4. Bası, Yetkin Yayınları, Ankara 2016. (Anılış: Mülkiyet Hukuku)

Ergüne, Mehmet Serkan, Taşınır Mülkiyeti, 1. Bası, On İki Levha Yayıncılık, İstanbul 2017. 
Esener, Turhan, Türk Hususi Hukukunda Muvazaalı Muameleler, Fakülteler Matbaası, İstanbul 1956. (Anılış: Muvazaalı Muameleler)

Esener, Turhan, Borçlar Hukuku I, Ankara Hukuk Fakültesi Yayınları No:246, Ankara 1969. (Anılış: Borçlar Hukuku I)

Fleischer, Holger (Hrsg.) / Goette, Wulf (Hrsg.), Münchener Kommentar zum Gesetz betreffend die Gesellschaften mit beschränkter Haftung (GmbHG), 2. Auflage, C. H. Beck, 2015. (MüKoGmbHG) İçinde: Reichert, Jochem/ Weller, Mark Philippe.

Gehrlein, Markus (Hrsg.) / Born, Manfred (Hrsg.) / Simon, Stefan (Hrsg.), GmbHG-Kommentar, 3. Auflage, Carl Heymanns Verlag, 2017. İçinde: Winter, Stephan.

Goette, Wulf (Hrsg.) / Habersack, Mathias (Hrsg.), Münchener Kommentar zum Aktiengesetz, C. H. Beck, 4. Auflage, 2016. İçinde: Hüffer/ Schäfer

Guhl, Theo/ Koller, Alfred/ Schnyder, Anton K./ Druey, Jean Nicholas, Das Schweizerische Obligationenrecht mit Einschluss des Handels - und Wertpapierrechts, 9. Auflage, Schulthess Juristische Medien AG, 2000.

Gürsoy, Kemal Tahir/ Eren, Fikret/ Cansel, Erol, Türk Eşya Hukuku, 2. Bası, Ankara Üniversitesi Hukuk Fakültesi Yayınları, Ankara 1984.

Handschin, Lukas, Gesellschaftsanteile und Gesellschafterversammlung - die Willensbildung in der GmbH - die Konzernleitung der GmbH, Das neue Recht der Schweizer GmbH-Recht, Schulthess Juristische Medien AG, Zürich-Basel-Genf 2006.

Helvacı, İlhan, Türk Medeni Kanunu’na Göre Lex Commissoria Yasağı, Yayımlanmamış Doktora Tezi, İstanbul 1997.

Henssler, Martin (Hrsg.) / Strohn, Lutz (Hrsg.), Gesellschaftsrecht, 3. Auflage, C. H. Beck, 2016. İçinde: Verse, Dirk A.

Hirte, Heribert, Kapitalgesellschaftsrecht, 8. Auflage, RWS Verlag, Köln 2016

Kılıçoğlu, Ahmet M., Borçlar Hukuku Genel Hükümler, Genişletilmiş 23. Bası, Turhan Kitabevi, Ankara 2019.

Kırca, İsmail/ Şehirali-Çelik, Feyzan Hayal/ Manavgat, Çağlar, Anonim Şirketler Hukuku, C. II/II, Genel Kurul Kararlarının Hükümsüzlüğü, ‘. Bası, Banka ve Ticaret Hukuku Araştırma Enstitüsü, Ankara 2017.

Kocayusufpaşaoğlu, Necip/ Hatemi, Hüseyin/ Serozan, Rona/Arpacı, Abdulkadir, Borçlar Hukuku Genel bölüm, C.I, 6. Bası, Filiz Yayınevi, İstanbul 2014.

Köprülü, Bülent/ Kaneti, Selim, Sınırlı Aynî Haklar, Genişletilmiş ve Yenilenmiş 2. Bası, İstanbul 1982-1983.

Kuntalp, Erden, “Lex Commissoria Yasağı Kavramı, Koşulları ve Uygulama Alanı”, İnan Kıraç’a Armağan, Galatasaray Üniversitesi Yayını, İstanbul 1994, s. 151 - 162.

Lieder, Jan/ Villegas, Diego, “Treuhandverträge über GmbH-Geschäftsanteile - eine Frage der Form?”, GmbHR 2018, s. 169-177.

Lutter, Marcus/ Hommelhof, Peter/ Bayer, Walter/ Kleindiek, Detlef, GmbH-Gesetz, 19. Auflage, Otto Schmidt Verlag, 2016.

Makaracı-Başak, Aslı, Taşınır Rehni Sözleşmesi, 1. Bası, On İki Levha Yayıncılık, İstanbul 2014.

Meier-Hayoz, Arthur (Hrsg.) / Kramer, Ernst A./ Schmidlin, Bruno, BK - Berner Kommentar Band/ Nr. VI/1/1, Schweizerisches Zivilgesetzbuch, Das Obligationenrecht, Allgemeine Bestimmungen, Allgemeine Einleitung in das schweizerische Obligationenrecht und Kommentar zu Art. 1-18 OR, Stämpfli Verlag AG, 1986.

Merz, Hans, "Legalzession und Aussonderungsrecht gemäß Art. 401 OR: ein Beitrag zum Verhältnis von Auftrag und fiduziarischem Rechtsgeschäft, Erhaltung und Entfaltung des Rechts in der Rechtsprechung des Schweizerischen Bundesgerichts", Helbing und Lichtenhahn, Basel 1975, s. 451-464. 
Michalski, Lutz (Hrsg.) / Heidinger, Andreas (Hrsg.) / Leible, Stefan (Hrsg.) / Schmidt, Jessica (Hrsg.) / Kommentar zum Gesetz betreffend die Gesellschaften mit beschänkter Haftung (GbmH-Gesetz), 3. Auflage, C.H. Beck, 2017. İçinde: Ebbing, Frank.

Moroğlu, Erdoğan, Anonim Ortaklıkta Genel Kurul Kararlarının Hükümsüzlüğü, Güncellenmiş ve Genişletilmiş 8. Baskı, On İki Levha Yayıncıllk, İstanbul 2017.

Mühl, Otto, "Der Geschäftsanteil in einer Gesellschaft mit beschränkter Haftung als Kreditsicherheit (treuhänderische Übertragung, Verpfändung, Nießbrauch)”, Gesellschaftsanteile als Kreditsicherheit, Duncker $§$ Humboldt, Berlin 1979.

Müller, Klaus/ Gruber, Urs, Sachenrecht, Vahlen Verlag, 2016.

Nomer, Haluk Nami, “Teminat Amaçlı Vefalı Satışlar ile İnanç Sözleşmeleri ve Lex Commissoria Yasağı”, Prof. Dr. Cevdet Yavuz’a Armağan, MÜHFD, C. 22, S. 3, s. 2007 - 2015.

Oğuzman, Kemal/ Seliçi, Özer/ Oktay-Özdemir, Saibe, Eşya Hukuku, 21. Bası, Filiz Kitabevi, Ekim 2018.

Oktay-Özdemir, Saibe, “Teminat Amaçlı Alacak Devri ve Toptan Temlik Sözleşmeleri”, İÜHFM, C. LVII, S. 1-2, Y. 1999, s. 265 - 299.

Özkaya, Erarslan, İnançlı İşlem ve Muvazaa Davaları, 7. Bası, Seçkin Yayıncılık, Ankara 2017.

Özsunay, Ergun, Türk Hukukunda ve Mukayeseli Hukukta İnançlı Muameleler, İstanbul 1968.

Özsunay, Ergun, “Saf İnançlı Muamelelerde Vekalet Sözleşmesine İlişkin Hükümlerin Uygulanması”, Temsil ve Vekalete İlişkin Sorunlar, Sempozyum, İstanbul 1977, s. 99-125. (Anılış: Saf İnançlı Muameleler)

Öztürk, Gülay, İnançlı İşlemler, Yetkin Yayınları, Ankara 1998.

Parlak-Börü, Şafak, “Mülkiyetin Teminat Amacıyla İnançlı İşlemle Devri”, TBB Dergisi 2017, C. 128, s. 231 272.

Poroy, Reha/ Tekinalp, Ünal/ Çamoğlu, Ersin, Ortaklıklar Hukuku I, 14. Bası, Vedat Kitapçılık, İstanbul 2019. (Ortaklıklar Hukuku I)

Ortaklıklar Hukuku II, 14. Bası, Vedat Kitapçılık, 2019. (Ortaklıklar Hukuku II)

Priester, Hans-Joachim (Hrsg.) / Mayer, Dieter (Hrsg.) / Wicke, Hartmut (Hrsg.), Münchener Handbuch des Gesellschaftsrechts, Band:3: Gesellschaft mit beschränkter Haftung, 5. Auflage, 2018. İçinde: Jasper, Dieter/ Wollbrink, Stephan ve Kraus, Martin.

Raiser, Thomas/ Veil, Rüdiger, Recht der Kapitalgesellschaften, 6.Auflage, 2015.

Roth, Herbert, “Pfändung und Verpfändung von Gesellschaftsanteilen”, ZGR 2000, s. 187-222.

Schimansky, Herbert. (Hrsg.) / Bunte, Hermann-Josef (Hrsg.)/ Lwowski, Hans Jürgen (Hrsg.), BankrechtsHandbuch, 5. Auflage, 2017. İçinde: Merkel, Helmut.

Schmid, Jörg (Hrsg.) / Jäggi, Peter/ Gauch, Peter/ Hartmann, Stephan, ZK - Zürcher Kommentar: Obligationenrecht: Art. 18 OR - Auslegung, Ergänzung und Anpassung der Verträge; Simulation, 4. Auflage, Schulthess Juristische Medien AG, Zürich 2014.

Schwerdtfeger, Armin (Hrsg.), Gesellschaftsrecht Kommentar, 3. Auflage, Carl Heymanns Verlag, 2015. İçinde: Buß, Thomas.

Serick, Rolf, Eigentumsvorbehalt und Sicherungsübertragung: Neue Rechtsentwicklungen, 2. Auflage, Heidelberg 1993.

Sirmen, Lale, Eşya Hukuku, Gözden Geçirilmiş 6. Bası, Yetkin Yayınları, 2018.

Şafak, Ali, Teminat Amaçlı Alacağın Temliki, 2. Basım, Seçkin Yayıncılık, Ankara 2017.

Şener, Oruç Hami, Limited Ortaklıklar Hukuku, Seçkin Yayıncılık, Ankara 2018. 
Tandoğan, Haluk, “İnançlı İşlemlerde İnananın Korunması Sorunu ve Bu Sorunun Çözümünde BK.393’ten Yararlanma Olanağı”, Temsil ve Vekalete İlişkin Sorunlar, Sempozyum, İstanbul 1977, s. 73-98. (Anılış: İnançli İşlemler)

Tandoğan, Haluk, Borçlar Hukuku - Özel Borç İlişkileri - Cilt: II, 5. Baskı, Vedat Kitapçılık, İstanbul 2010. (Anılış: Özel Borç İlişkileri)

Tuncer-Kazancı, İdil, “İnançlı İşlemde İşlemin Taraflarının İflası ve İflasın İnançlı İşleme Etkisi”, Prof. Dr. Hakan Pekcanıtez’e Armağan, DEÜHFD, C. 18, Özel Sayı 2014, s. 2811 - 2834.

Uygur, Atiye, “Teminat Amaçlı İnançlı İşlemler”, Gazi Üniversitesi Hukuk Fakültesi Dergisi, C.X, S.1-2, 2006, s. 171-195.

Vardar-Hamamcıŏlu, Gülşah, Medeni Hukuk’ta Tasarruf İşlemi Kavramı, On İki Levha Yayıncılık, İstanbul 2014.

Wicke, Harmut, GmbHG, 3. Auflage, C. H. Beck, 2016.

Yasaman, Hamdi, “Hisse Devir İşlemi”, Şirketler Hukuku Ve Sermaye Piyasası Hukuku İle İlgili Makaleler, Mütalaalar, Bilirkişi Raporları-II, Vedat Kitapçılık, İstanbul 2013, s. 563-586.

Yılmaz, Süleyman/ Pınar, Hamdi, "İnançlı İşlemlerin Muvazaalı İşlemlerle Karşılaştırılması Üzerinde Bir Değerlendirme”, AÜHFD, C. 68, S. 4, Y. 2019, s. 959 - 998. 


\section{KISALTMALAR}

AATUHK : 6183 sayılı Amme Alacaklarının Tahsili Usulü Hakkında Kanun

Abs.

: Absatz

AÜHFD : : Ankara Üniversitesi Hukuk Fakültesi Dergisi

Art.

: Artikel

BATIDER : Banka ve Ticaret Hukuku Dergisi

Bkz. : : Bakınız

BGE : Bundesgerichtsentscheidungen

BRAO : Bundesrechtsanwaltsordnung

C.

: Cilt

DEÜHFD : : Dokuz Eylül Üniversitesi Hukuk Fakültesi Dergisi

dn. $\quad$ : dipnot

eTMK : 743 sayılı Türk Kanunu Medenîsi

$\mathrm{GmbH} \quad$ : Gesellschaft mit beschränker Haftung

GmbHG : : Gesetz betreffend die Gesellschaften mit beschränker Haftung

HD : Hukuk Dairesi

HMK : 6100 sayılı Hukuk Muhakemeleri Kanunu

Hrsg. : : Herausgeber

İ́K : 2004 sayılı İcra ve İflas Kanunu

IÜHFM : : İstanbul Üniversitesi Hukuk Fakültesi Mecmuası

$\mathrm{N} \quad$ : Numara

Nr. : Numara

p. : paragraf

RG : Resmi Gazete

Rn. : Reihennummer

S. $\quad$ : Say1

s. $\quad$ : Sayfa

TMK : 4721 sayılı Türk Medeni Kanunu

TTK : 6102 sayılı Türk Ticaret Kanunu

vd. $\quad$ : ve devamı

Y. : : Yll

Yarg. : Yargitay

ZGB : Schweizerisches Zivilgesetzbuch

ZGR : Zeitschrift für Unternehmens - und Gesellschaftsrecht 